\title{
MAGYARORSZÁGOT ÉRINTŐ MAGYAR NEMZETKÖZI VÁNDORLÁSOK A KÁRPÁT- MEDENCÉBEN 2011 ÉS 2017 KÖZÖTT
}

\section{Kincses Áron}

\section{ÖSSZEFOGLALÓ}

A Magyarországot érintő nemzetközi vándorlásnak két szintjét különböztethetjük meg, melyek markánsan eltérnek egymástól: a globális migrációs hatás, valamint a környező országok és hazánk közötti folyamatok. A nemzetközi migráció hazai jellegzetessége, hogy a bevándorló népesség nagy része magyar nemzetiségü, ami részben az I. és II. világháborút lezáró békeszerződések következménye.

A külhoni területekről Magyarországra történő vándorlások a magyarság Kárpát-medencei összlétszámát rövidtávon nem változtatják meg, azonban hosszabb időhorizonton csökkenthetik, mivel az etnikai térszerkezetre jelentős befolyásuk van: lokálisan, az elvándorlási térségekben a magyarok számával arányosan csökkennek a lehetőségek, és a szórványosodással párhuzamosan megjelenhet az asszimiláció. A rendszerváltás utáni népességmozgások tették egyértelművé, hogy a magyar nyelvközösség körében lejátszódó demográfiai folyamatokat - az 1918-ban bekövetkezett széttagoltság, és a közel 100 éves „szétfejlődés” ellenére - csak akkor ismerhetjük meg, ha azokat együtt, egységes folyamatként vizsgáljuk. Mindaz, ami Magyarországon zajlik, csak része a magyar nyelvközösség népesedési folyamatainak, de nem azonos azzal. Cél ezáltal nemcsak a magyarországi, hanem a Kárpát-medencei magyarság létszámcsökkentésének megállítása is lehet. Ennek megvalósítása nem egyszerű feladat, mert ellentétes a szomszédos országok nemzeti érdekeivel. 
A Kárpát-medence országaiból a nem magyarok lakta területekről érkezők száma növekszik, újra megfigyelhető hazánkban a nem magyar etnikumúak aszszimilációja, melyben az 1918 előtti idők demográfiai folyamatait ismerhetjük fel. Kérdés tehát, hogy a mai magyar népességfejlődés mennyire lehet folytatása az 1918-as évet megelőző évszázadoknak.

A tanulmányban leírt vándorlási folyamatok jelentős hatással lennének a magyarság Kárpát-medencei etnikai térszerkezetére és létszámára, ha a többi etnikum száma nem csökkenne hasonlóan a magyarhoz. A szülőföldön maradás erősödése, a visszavándorlások számának, illetve a helyi magyarság termékenységi rátájának emelkedése jelenthetne megoldást a problémára. Mindezzel talán elérhető lenne, hogy a Kárpát-medencében újra 50\% fölé emelkedjen a magyar nemzetiségủek aránya. Ennek a folyamatnak jelenleg legnagyobb gátja az a népességveszteség, amely az alacsony termékenység, a magas halálozás következtében a Kárpát-medence magyar népességét éri.

Tárgyszavak: demográfia, Kárpát-medence, nemzetközi vándorlás, statisztika

Kincses Áron, elnökhelyettes, KSH Szakstatisztikai Igazgatóság

\section{BEVEZETÉS}

Napjainkban sokkal több szó esik a Magyarországról kivándorlókról (Blaskó és Gödri, 2016, Siskáné et al., 2017, Egedy, 2017), mint a hazánkba legálisan külföldről érkezőkről, vagy a Kárpát-medence többi országából elvándorló magyarokról. Jelen írás e két utóbbi jelenség metszetét igyekszik górcső alá venni, a Kárpát-medence országaiból Magyarországra települőkre koncentrálva. A tanulmány a Magyarországon élő, külföldi kötődésű népesség számosságát, társadalmi-demográfiai, gazdasági tulajdonságait mutatja be a forrás és a célterületek szempontjából, feltárva a migrációs forrásterületeket és a Kárpát-medencei magyar népesedési hatásokat. Demográfiai, közgazdaságtani, szociológiai és geográfiai szempontból a Magyarországot érintő migráció kutatásában inkább a fogadó területeken keletkező hatások vizsgálata hangsúlyos. Ez alapvetően két okra vezethető vissza. Egyrészt a magyarországi kö- 
vetkezmények elemzése ezt a megközelítési módot kívánja meg, másrészt az elvándorlási térségek többnyire nehezen azonosíthatók be, ami megnehezíti a Kárpát-medencére kiterjedő kutatásokat. A hivatalos statisztikai adatok felhasználásával és adat-összekapcsolásokkal lehetőség nyílik e hiátus megszüntetésére és a vándorlási jelenségek átfogóbb vizsgálatára, hiszen a demográfiai folyamatokat nem érdemes csak a jelenlegi országhatárokon belül vizsgálni. Az elemzés tág halmazon értelmezi a nemzetközi vándorlásban érintetteket, ezért nem pusztán a külföldi állampolgárok mozgására koncentrál, hanem a külföldön született, honosított magyar állampolgárokkal együtt vizsgálja a vándorlás hatásait.

\section{AZ ELEMZÉS KERETEI, AZ ADATOK FORRÁSA}

A Magyarországon élő külföldi állampolgárokról számos adatforrás áll rendelkezésünkre, melyek túlnyomó része adminisztratív nyilvántartás. Ezeket az adatállományokat vagy regisztereket annak érdekében hozta létre egy közigazgatási szervezet (adóügy, társadalombiztosítás stb.), hogy a saját, jogszabályban meghatározott igazgatási feladatainak végrehajtását támogassa (Gárdos et al., 2008). Ezekben az esetekben nem a statisztikai, kutatási igények határozzák meg elsődlegesen a koncepciót és a tartalmat, a célsokaság egységeit, az adatok vonatkozási idejét és a definíciókat sem. További nehézséget jelent, hogy a jogszabályok változásával a nyilvántartás tartalma és szerkezete módosulhat. Mindez azt jelenti, hogy az esetek egy részében nehéz ezekből az adatrendszerekből közvetlenül kinyerni a statisztika igényeinek megfelelő információkat, ugyanakkor ezek az adatok rendszeresen, megbízhatóan, hivatalos okmányokkal alátámasztottan állnak rendelkezésre.

A Belügyminisztérium adminisztratív adatbázisában azok a külföldi állampolgárok szerepelnek, akik az adott év január 1-jei nyilvántartási állapot szerint legalább 12 hónapra szóló tartózkodásra jogosító engedéllyel rendelkeznek (a hontalanokkal, menekültekkel és oltalmazottakkal együtt), míg a külföldön születettek azok a külföldi (a hontalanokkal, menekültekkel és oltalmazottakkal együtt), valamint magyar állampolgárok, akiknek születéskori lakóhelye a mai Magyarország területén kívül található.

A cenzusszerü adatok előnye az adminisztratívakkal szemben az, hogy mindenkit az életvitelszerü lakóhelyéhez lehet kötni, a kérdőívben megkérdezett minden változójával együtt. Ez biztosítja a lehetőséget arra, hogy Magyarország összes lakosának életkörülményei, gazdasági, képzettségi, szociális háttere sta- 
tisztikai célra területi bontásokban is megismerhetővé váljon. Az összeírásra az egész országban egyidejüleg, azonos tartalommal és egységes módszertani alapon kerül sor. Azokról készül adatfelvétel, akik magyar állampolgárok és az ország területén életvitelszerüen élnek, vagy ha külföldön vannak, akkor csak átmenetileg (12 hónapnál rövidebb ideig) tartózkodnak ott; illetve azok a külföldi állampolgárok és hontalan személyek is összeírásra kerülnek, akik az ország területén meghatározott ideje tartózkodnak. A külföldi állampolgárok közül nem kerülnek számbavételbe a diplomáciai testületek tagjai és családtagjaik; az országgyűlés vagy a kormány határozata alapján hazánkban állomásozó külföldi fegyveres erők tagjai; illetve a turizmus (pihenés, kirándulás, vadászat stb.), látogatás, gyógykezelés, üzleti tárgyalás stb. céljából hazánkban tartózkodó személyek. Ugyanakkor ezek az információk nem állnak rendelkezésre olyan gyakorisággal, mint az adminisztratív nyilvántartásokban.

A dolgozatban ez említett kétfajta statisztikai adatforrást használtam fel. A téma szempontjából releváns magyar migrációs adatbázisok (Személyiadatés lakcímnyilvántartás, a BMH külföldiekre vonatkozó nyilvántartásai'; Népszámlálás, Mikrocenzus) 2011-es és 2017-es állományi adataival dolgoztam. Az elemzések alapjául szolgáló adatok nem voltak közvetlenül elérhetők, így külön besorolásokra volt szükségem a területi hatások vizsgálatához. A nemzetközi vándorlások Kárpát-medencei forrástelepüléseinek, térségeinek feltérképezése lehetővé teszi a Kárpát-medencét érintő vándorlási folyamatok mélyebb megértését. Az adminisztratív forrásokban jelenleg országok szerinti besorolások automatizáltak, a külföldi települések listája számos kihívást tartogatott: gépelési hibák, elírások, különböző nyelveken megadott városnevek nehezítették az előrehaladást. Egy-egy nagyobb város többszázféleképpen került rögzítésre, illetve sok esetben olyan településrészek kerültek megadásra, melyek ma már nem számítanak önállónak².

Mindkét adatforrás tartalmaz olyan információkat, melyek a másik állományból hiányoznak, (a mikrocenzusban megtalálhatók iskolai végzettségre, gazda-

\footnotetext{
${ }^{1}$ A Személyiadat- és lakcímnyilvántartás tartalmazza a magyarok, a hontalanok, a menekültek és az oltalmazottak, míg a BMH a többi külföldi állampolgár adatát fogja össze.

${ }^{2}$ Csak néhány példa:

- Székelyhidegkút (románul Vidacutu Român, németül Kaltenbrunnen) hajdani falu a mai Romániában, Hargita megyében. Magyarhidegkút és Oláhhidegkút 1926-os egyesítéséből keletkezett. A falu északi része Magyar-, nyugati része Oláhhidegkút. Jelenleg Hidegkút településrésze.

- Hidegkút (románul Vidăcut) ma falu Romániában, Hargita megyében. Közigazgatásilag Székelyandrásfalvához tartozik.

- Horthyvára: Máriamajor (szerbül Степановићево/Stepanovićevo, 1941-1944 között Horthyvára, 1941-ben rövid ideig Bácshadikfalva nevet viselte), ma Újvidék községhez tartozó falu Szerbiában, a Vajdaságban, a Dél-bácskai körzetben.

- Kadicsfalva - (Cadiseni) ma Székelyudvarhely városrésze (A krónikák szerint 1566-ban a Kadichfalva nevet viselte).

- Csekelaka (románul: Cecălaca) falu Romániában, Maros megyében. Közigazgatásilag ma Cintos községhez tartozik.
} 
sági aktivitásra vonatkozó adatok, melyek nem részei a BM nyilvántartásának, viszont az adminisztratív adatbázis tartalmazza a születési településeket) ezért a két állomány összekapcsolására volt szükség³. Ehhez többlépcsős kulcsrendszert alkalmaztunk a nem, születési év, hónap, a magyarországi lakóhely településének neve, közterület neve és a házszám felhasználásával. Ahol szükséges volt, aránybecslést használtam4 4 .

2011-ben a népszámláláshoz kapcsoltuk hozzá az adminisztratív adatokat (a népszámlálások vonatkozási évében ez a forrása a hivatalos statisztikai adatoknak), míg 2017-ben a BM nyilvántartáshoz illesztettük a mikrocenzus információit (népszámláláson kívüli években az adminisztratív állományok adják a hivatalos statisztikát, míg az ettől eltérő időszakokban a BM nyilvántartásai). Ezért a 2017-es megoszlások kismértékben eltérhetnek a mikrocenzus eredményeitől, így mindkét vizsgált évre egy-egy összekapcsolt állomány állt rendelkezésünkre. Ezekből származnak a tanulmányban ismertetett adatok. Az eljárás előnye, hogy az adatbázisokban lévő egyes változók megoszlásai külön-külön megegyeznek az eredeti állományukban lévőkkel, ami azokra a kereszttáblázatokra is igaz, ahol az információk két különböző forrásból származnak.

\section{A KÜLFÖLDI KÖTÖDÉSÜ NÉPESSÉG MAGYARORSZÁGON}

\section{Mennyiség és állampolgárság}

Hazánk nemzetközi migrációs tere folyamatosan szélesedik, Magyarországon is tapasztalhatók a globális migrációs tendenciák (Hatton and Williamson, 2005): a jelenleg itt élő külföldi állampolgárok 175 különböző országból érkeztek. Az Európából érkezők aránya folyamatosan csökken: míg 1995-ben a külföldiek 89\%-a kontinensünkről érkezett, addig ez az arány 2017-re 65\%-ra mérséklődött. Azonban az Európán kívülről érkezettek döntő többsége nem magyar anyanyelvü.

\footnotetext{
${ }^{3}$ A munkában a Népszámlálási és népesedésstatisztikai főosztály főosztályvezetője Kovács Marcell és szakértői, Ináncsi Zita és Novák János nélkülözhetetlen segítséget nyújtottak. Támogatásukat ezúton is köszönöm.

${ }^{4}$ Az összekapcsolások a különböző adatbázisok között 60-75\%-ban voltak sikeresek. Az egyes részcsoportokban nem voltak szignifikáns eltérés az összekapcsolási arányokban. Aránybecslésekkel csak azokban az esetekben kellett élni, amikor a két eredeti adatállomány különböző változóinak kereszttáblázatait vizsgáltam. Ez az iskolai végzettség, gazdasági aktivitás, anyanyelv és a gyereket nevelő háztartások születési régiók szerinti elemzésénél fordult elő.
} 
Ugyanakkor Magyarország globális értelemben (Hatton and Williamson, 2005, Krugman and Venables, 1996, Venables, 1998) nem tekinthető tipikus befogadó országnak. Egyrészt a migráció volumene, népességhez viszonyított aránya jelentősen kisebb, mint a nagy befogadó országokban (1. ábra), másrészt a világ migrációjában érvényesülő globális tendenciák csak kisebb mértékben éreztetik hatásukat. Hazánkban inkább a kis távolságú nemzetközi vándorlások a jellemzők, mely alapján arra következtethetünk, hogy (bár csökkenő mértékben) egyelőre továbbra is az európaiak számára jelent célpontot.

1. ábra: A külföldön születettek népesség aránya egyes országokban, 2017*

The foreign-born population in some countries, 2017

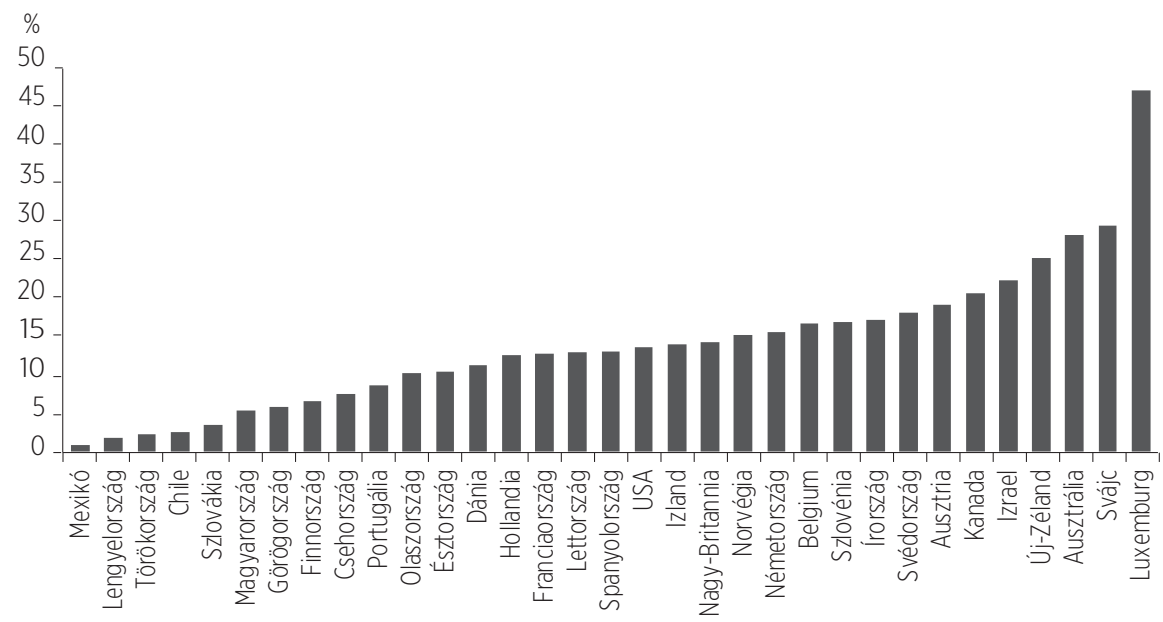

* Lengyelországra csak 2011-re áll rendelkezésre adat.

Forrás: OECD, SOPEMI, 2018;

Európán belül a szomszédos országok kiemelt súlya összefügg a határokon túl nyúló nyelvi, kulturális kapcsolatokkal, amely főként egyirányú mozgást jelent, azaz a szomszédos országokból nagyságrendekkel többen érkeznek hazánkba, mint fordítva. Tehát az I. és II. világháborút lezáró békeszerződések következményei ma is meghatározó szerepet tölt be a Kárpát-medence migrációs folyamataiban (Tóth, 2005).

Magyarország esetében nemcsak a hazai viszonyok meghatározók a nemzetközi vándorlás vizsgálata során, hanem a szomszédos országok magyar népességének általános állapota is. Továbbá a környező országok gazdasági helyzete, kisebbséggel kapcsolatos politikája, vagy Magyarország vonzó hatása is meghatározó abban, milyen mértékủ legális nemzetközi vándorlással 
lehet és szükséges az országnak jelenleg és az elkövetkező évtizedekben is számolnia (Tóth, 1997).

A Magyarországon élő nemzetközi vándorlókat sokszor az itt élő külföldi állampolgárokra leegyszerüsítve vizsgálják, ugyanakkor a migrációban érintett csoport ennél sokkal nagyobb számosságú, struktúrája árnyaltabb.

Ha pusztán az előbb említett populációt vizsgáljuk, azt találjuk, hogy a külföldi állampolgárok 2011-ben mért 143197 fős száma mindössze 5,5\%-kal növekedett 2017-re, amikor is 151132 fö élt hazánkban. A globális migrációs tendenciáknak köszönhetően 2017-ben például már több kínai állampolgár tartózkodott Magyarországon, mint román. Azonban ez az adat további magyarázatra szorul.

A bevándorlás hatásainak, mértékének vizsgálata során nem feledkezhetünk meg a honositásokról sem úgy, mint a külföldön született, de már Magyarországon élő magyar állampolgárokról5. Ezen személyek száma jelentősen meghaladja a külföldi állampolgárokét. A két említett csoport együttesen fedi le a vizsgálni kivánt célsokaságot, a Magyarországon élő, külföldi kötődésủ népességet (a külföldi állampolgárok és a külföldön született magyar állampolgárok diszjunkt halmazai együttesen alkotják ezt a csoportot). E csoporton belül a külföldi állampolgárok súlya folyamatosan csökken: míg 2011-ben 37\%, addig 2017-ben már csak 29\%-ot mérhetünk.

A Magyarországon élő külföldi kötődésü népesség 2017-ben 521258 fő volt, mely 33\%-ot emelkedett 2011 óta, és nem számolva bele a vizsgált célsokaságba azokat a kivándorló magyarokat, akik később visszatértek Magyarországra (127 ezer fő). Ezek a számok árnyalják azt a kijelentést, hogy Magyarország nemzetközi vándorlási egyenlege negatív (Juhász et al., 2017).

Mindemellett azt is látni kell, hogy a honositottak többsége a szomszédos országokból érkezik. 2011-ben 288024 fő élt Magyarországon, akik a Kárpátmedence országaiból érkeztek, számuk 2017-re 22\%-kal emelkedett (352 506 fő, melyből 313 ezer magyar nemzetiségű). Ma a Romániában született, Magyarországon élő személyek száma magasabb, mint Debrecen (az ország második legnagyobb városa) teljes lakossága. A vizsgált időszak alatt egyedül a Szlovákiából érkezők száma csökkent, míg a többi szomszédos országban születetteké dinamikusan emelkedett. A táblázatból láthatjuk, hogy az Ukrajnából bevándorlók esetén nőtt a legnagyobb arányban, 81\%-kal.

\footnotetext{
${ }^{5}$ Az egyszerüsített honositási eljárás keretében, magyarországi lakcímmel nem rendelkező személy vizsgálata nem része a tanulmánynak. Ennek bevezetésével mintegy tízszer annyian szerezték meg a magyar állampolgárságot, mint ahány belföldi, számuk 2011 és 2015 között már közel 650 ezer fő volt (KSH, 2017).
} 
1. táblázat: A külföldön született magyar állampolgárok és a külföldi állampolgárok föbb országok szerint, 2011, 2017

Foreign-born Hungarian and foreign citizens according to the main countries, 2011, 1017

\begin{tabular}{|c|c|c|c|c|c|c|}
\hline \multirow[b]{2}{*}{$\begin{array}{c}\text { Állampolgárság } \\
\text { országa/születési } \\
\text { hely }\end{array}$} & \multicolumn{3}{|c|}{2011} & \multicolumn{3}{|c|}{2017} \\
\hline & $\begin{array}{l}\text { Külföldi } \\
\text { állampolgár }\end{array}$ & $\begin{array}{l}\text { Külföldön } \\
\text { született } \\
\text { magyarok }\end{array}$ & $\begin{array}{l}\text { Külföldi } \\
\text { kötődésű } \\
\text { népesség } \\
\text { összesen }\end{array}$ & $\begin{array}{l}\text { Külföldi } \\
\text { állampolgár }\end{array}$ & $\begin{array}{l}\text { Külföldön } \\
\text { született } \\
\text { magyarok }\end{array}$ & $\begin{array}{l}\text { Külföldi } \\
\text { kötődésű } \\
\text { népesség } \\
\text { összesen }\end{array}$ \\
\hline Románia & 38574 & 139093 & 177667 & 24040 & 182387 & 206427 \\
\hline Németország & 16987 & 7294 & 24281 & 18627 & 16039 & 34666 \\
\hline Szlovákia & 8246 & 25195 & 33441 & 9519 & 17376 & 26895 \\
\hline Ausztria & 3936 & 2897 & 6833 & 4021 & 7102 & 11123 \\
\hline Nagy-Britannia & 2602 & 1184 & 3786 & 3081 & 8578 & 11659 \\
\hline Franciaország & 2201 & 1123 & 3324 & 2523 & 2156 & 4679 \\
\hline Hollandia & 2058 & 461 & 2519 & 2814 & 1208 & 4022 \\
\hline EU28 & 85414 & 183761 & 269175 & 76270 & 248524 & 324794 \\
\hline Ukrajna & 11820 & 23953 & 35773 & 5774 & 59272 & 65046 \\
\hline Szerbia & 7752 & 21306 & 29058 & 2312 & 37497 & 39809 \\
\hline Európa egyéb & 7536 & 8764 & 16300 & 14838 & 5463 & 20301 \\
\hline Európa összesen & 112522 & 237785 & 350307 & 99194 & 350756 & 449950 \\
\hline Kína & 8852 & 939 & 9791 & 19111 & 415 & 19526 \\
\hline Vietnám & 2358 & 728 & 3086 & 3256 & 825 & 4081 \\
\hline Irán & 1523 & 163 & 1686 & 2444 & 248 & 2692 \\
\hline Ázsia egyéb & 9571 & 2930 & 12501 & 15126 & 5051 & 20177 \\
\hline Ázsia összesen & 22304 & 4760 & 27064 & 39937 & 6539 & 46476 \\
\hline $\begin{array}{l}\text { Amerikai Egyesült } \\
\text { Államok }\end{array}$ & 3022 & 1924 & 4946 & 3198 & 5294 & 8492 \\
\hline Kanada & 484 & 807 & 1291 & 513 & 2218 & 2731 \\
\hline Amerika egyéb & 1237 & 1054 & 2291 & 1686 & 1637 & 3323 \\
\hline Amerika összesen & 4743 & 3785 & 8528 & 5397 & 9149 & 14546 \\
\hline Nigéria & 1015 & 105 & 1120 & 1475 & 192 & 1667 \\
\hline Egyiptom & 472 & 176 & 648 & 1182 & 567 & 1749 \\
\hline Afrika egyéb & 1366 & 909 & 2275 & 3328 & 1639 & 4967 \\
\hline Afrika összesen & 2853 & 1190 & 4043 & 5985 & 2398 & 8383 \\
\hline $\begin{array}{l}\text { Ausztrália és } \\
\text { Óceánia }\end{array}$ & 775 & 360 & 1135 & 619 & 1284 & 1903 \\
\hline Összesen & 143197 & 247870 & 391067 & 151132 & 370126 & 521258 \\
\hline
\end{tabular}

Forrás: KSH. 


\section{Demográfiai, iskolázottsági és munkaerő-piaci jellemzők}

A legtöbb vizsgálat kiemeli, hogy Magyarországon a külföldi kötődésủ népesség fiatalabb az autochton populációnál (Gödri, 2012), így a vándorlásnak fiatalító hatása van. Ez az állítás a külföldi állampolgárokra (38,8 év az átlagéletkor), különösen a nőkre igaz. A külföldön született magyar állampolgárok azonban idősebbek (43,9 év) a lakónépességnél (41,7 év). A vizsgált évek során a külföldi kötődésű népesség átlagéletkora jelentősen csökkent (2011-es 47,1 évről 42,6 évre), aminek hátterében a rendszerváltás után hazánkba bevándorló, mára időskorú népesség fokozatos elvesztése (halálozása) áll. A nem Magyarországon születettek között kevesebb a gyermekek száma, és összességében magasabb az aktív korúak aránya, mely különösen igaz a külföldi állampolgárokra.

2. ábra: A lakónépesség és a külföldi kötődésü népesség korcsoportok szerint, 2017. január 1. Resident population and foreign population by age group, January 1, 2017

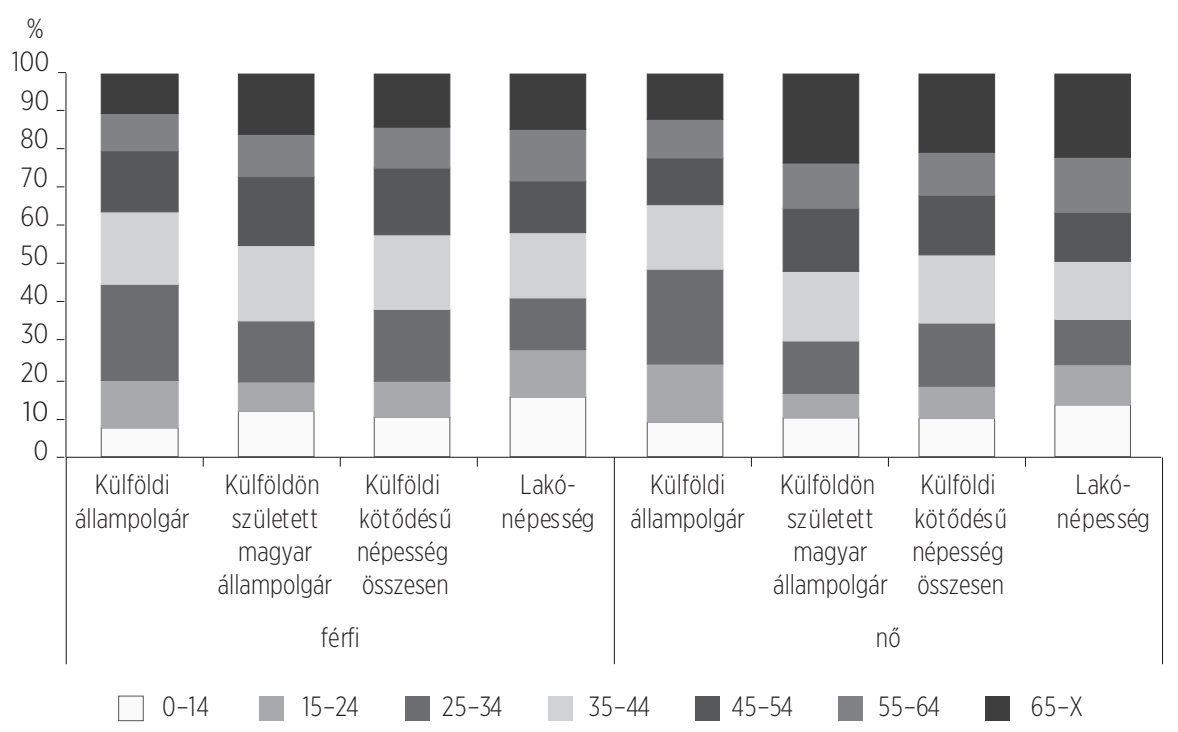

Forrás: Saját kalkuláció a BM és a KSH adatok alapján.

A külföldi kötődésủ népesség iskolai végzettsége magasabb a Magyarországon születettekénél: 2017-ben a Magyarországon élő külföldi, 24 év feletti népesség csaknem 46\%-a, a külföldön született magyar állampolgárok több, mint harmada 
felsőfokú végzettséggel rendelkezett. Az iskolai végzettségekben tapasztalható jelentős eltérések nagyrészt a korszerkezet különbségeire vezethetők vissza.

3. ábra: A lakónépesség és a külföldi kötődésü (25 éves és idősebb) népesség iskolai végzettségek szerint, 2017. január 1.

Resident population and foreign population (25 years old and elder) by education, January 1, 2017

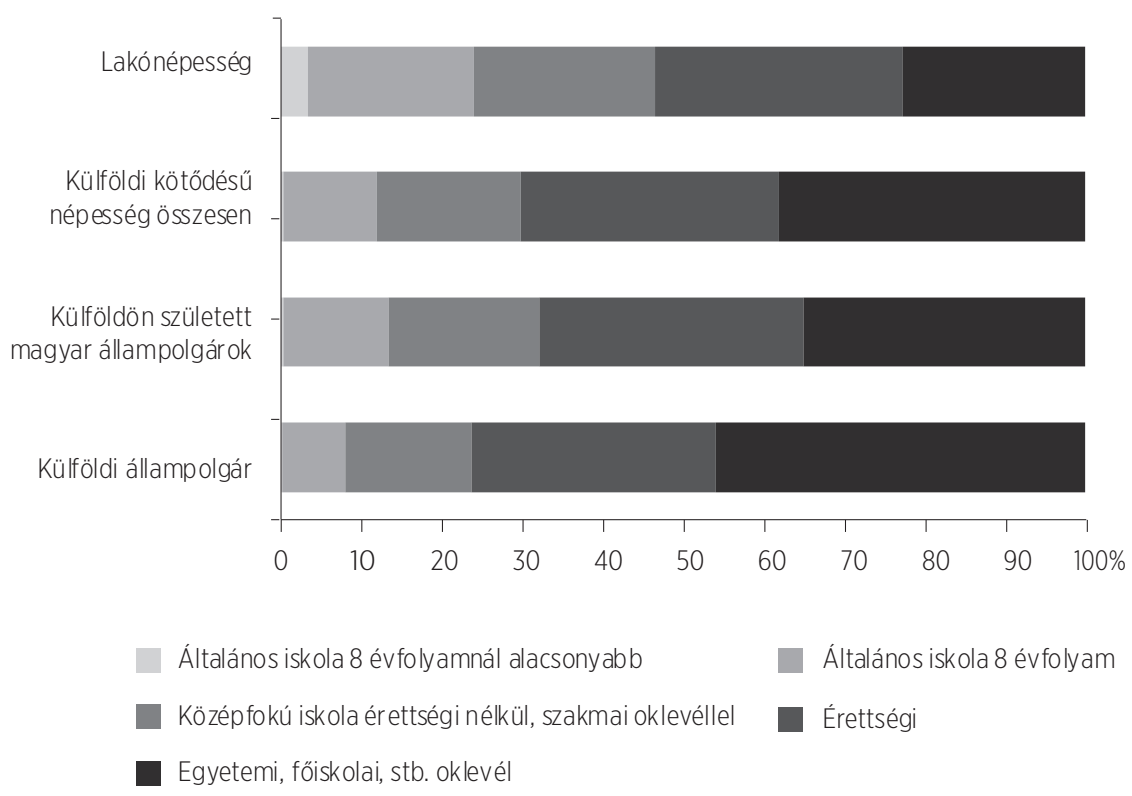

Forrás: Saját kalkuláció a BM és a KSH adatok alapján.

Az iskolai végzettséggel hozható összefüggésbe, hogy a nemzetközi vándorlók Magyarországon a rendszerváltás óta magas foglalkoztatottsági rátával rendelkeznek. Az utóbbi évek tendenciája, hogy a lakónépesség gazdasági aktivitása megközelíti a külföldi kötődésű népességéét, a munkanélküliségi rátájuk már kedvezőbb, mint a másik két vizsgált csoporté. Az inaktív keresők nagy része nyugdíjas, illetve gyermekgondozási (nevelési) ellátásban részesülő. Mindkét jogcím jobban jellemzi az autochton populációt, mint a külföldi kötődésű népességet. Az eltartottak csoportján belül a lakónépesség tizede nappali tagozatos tanuló, míg a nemzetközi vándorlókra a ráta jóval magasabb, 14\% és 23\% között mozog. 
2. táblázat: A 25-64 éves bevándorlók és a lakónépesség megoszlása gazdasági aktivitás szerint, 2017 The distribution of immigrants aged 25-64 and the resident population according to theirs economic activity, 2017

\begin{tabular}{|c|c|c|c|c|}
\hline Gazdasági aktivitás & $\begin{array}{c}\text { Külföldi } \\
\text { állampolgár }\end{array}$ & $\begin{array}{c}\text { Külföldön } \\
\text { született } \\
\text { magyar } \\
\text { állam- } \\
\text { polgárok }\end{array}$ & $\begin{array}{l}\text { Külföldi } \\
\text { kötődésű } \\
\text { népesség } \\
\text { összesen }\end{array}$ & $\begin{array}{l}\text { Lakó- } \\
\text { népesség }\end{array}$ \\
\hline Foglalkoztatott & 81,3 & 80,2 & 80,5 & 75,1 \\
\hline Munkanélküli & 3,8 & 3,7 & 3,8 & 3,5 \\
\hline Gazdaságilag aktív népesség együtt & 85,1 & 83,9 & 84,3 & 78,6 \\
\hline Inaktív kereső & 7,6 & 11,0 & 10,0 & 17,3 \\
\hline Eltartott & 7,3 & 5,1 & 5,7 & 4,1 \\
\hline Gazdaságilag nem aktív népesség együtt & 14,9 & 16,1 & 15,7 & 21,4 \\
\hline Összesen & 100,0 & 100,0 & 100,0 & 100,0 \\
\hline
\end{tabular}

Forrás: Saját kalkuláció a BM és a KSH adatok alapján.

Az egyének jelenlegi, illetve az utolsó foglalkozásukat, munkakörüket tekintve a külföldi állampolgárok enyhén felülreprezentáltak a felsőfokú képzettség önálló alkalmazását igénylő foglalkozásokban a lakónépességhez képest, amit predesztinált a magas felsőfokú végzettséggel rendelkezők aránya. Összességében a külföldi kötődésű népesség foglalkozások szerinti eloszlása jelentősen nem különbözik a lakónépességétől, jelezve ezzel, hogy sokkal inkább a piaci igények váltak meghatározóvá Magyarországon az elmúlt időszakban, amelyhez alkalmazkodik a munkaerő kínálata is. 
4. ábra: A 25-64 éves bevándorlók és a lakónépesség megoszlása foglalkozási föcsoportok szerint, 2017

The distribution of immigrants aged 25-64 and the resident population according to theirs jobs, 2017

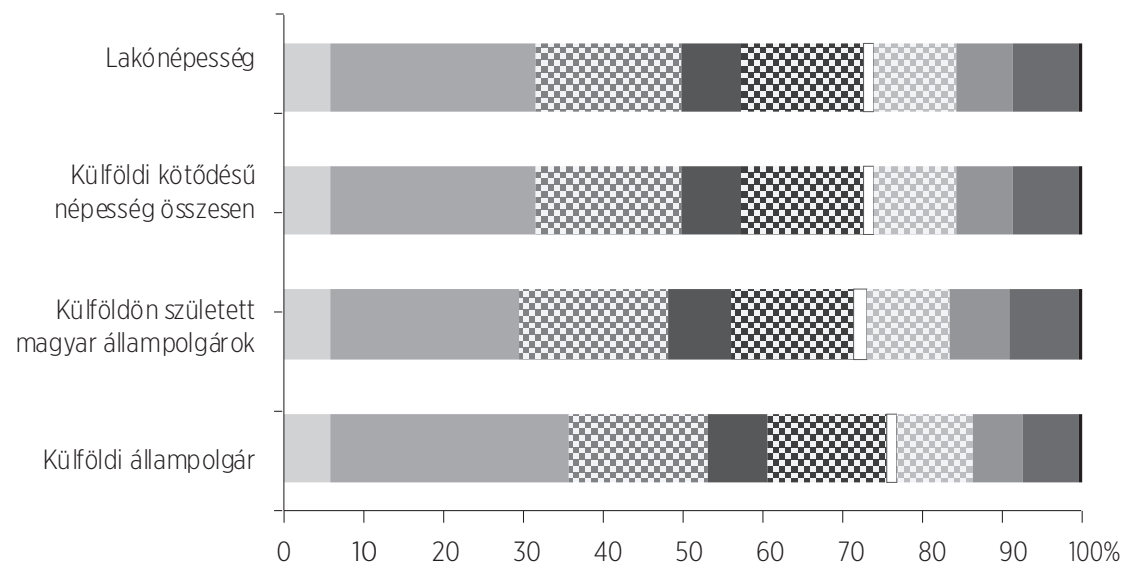

Gazdasági, igazgatási, érdek-képviseleti vezetők, törvényhozók

Felsőfokú képzettség önálló alkalmazását igénylő foglalkozások

Bgyéb felsőfokú vagy középfokú képzettséget igénylő foglalkozások

Irodai és ügyviteli (ügyfélkapcsolati) foglalkozások

3. Kereskedelmi és szolgáltatási foglalkozások

— Mezőgazdasági és erdőgazdálkodási foglalkozások

GI Ipari és építőipati foglalkozások

Gépkezelők, összeszerelők, járművezetők

Szakképzettséget nem igénylő (egyszerű) foglalkozások

- Fegyveres szervek foglalkozásai

Forrás: Saját kalkuláció a BM és a KSH adatok alapján.

\section{Területi jellemzők}

A belföldi vándorlásokra jellemző, hogy a jobb munkaerő-piaci pozíciókkal rendelkező társadalmi csoportok a kedvezőbb gazdasági mutatókkal, és imázzsal rendelkező, a települési hierarchia magasabb fokán lévő, nagyobb településekre vándorolnak (Bálint et al., 2017), ezzel is erősítve a térbeli társadalomszerkezet differenciáit, a különböző presztízsű társadalmi csoportok területi elkülönülését. 
5. ábra: A külföldi kötődésű- és a lakónépesség megoszlása a jelenlegi lakóhely jogállása szerint, 2017

The distribution of foreign population and resident population according to theirs permanent adress, 2017

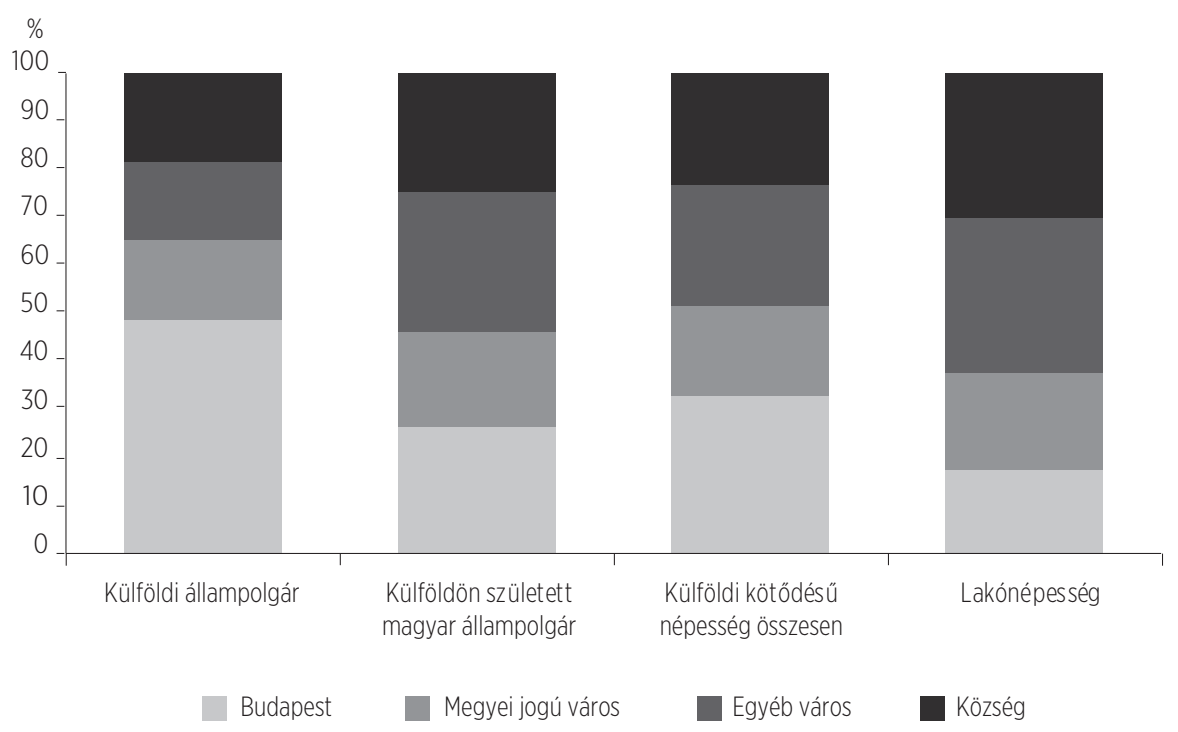

Forrás: Saját kalkuláció a BM és a KSH adatok alapján.

A nemzetközi vándorlásra ezek a megállapítások csak részben jellemzők, mert a jövedelmi lehetőségek mellett fontosabb szerep jut a desztinációk területi elhelyezkedésének és a természeti környezetnek (Balaton vonzó hatása a nyugat-európai nyugdíjasok számára) (Dövényi, 2011). A külföldi kötődésü népesség területi eloszlása különbözik a Magyarországon születettekétől, az országos hatásokat így jelentősen felülmúlhatják az általuk preferált térségekben érezhető befolyásuk.

Három térséget emelhetünk ki migrációs szempontból, melyben általánosan és tartósan nagyobb számban és arányban vannak jelen a vizsgált vándorlási csoportok: Közép-Magyarországot, a határmenti járásokat és a Balaton térségét.

Budapest és Pest megye vonzza a legnagyobb távolságból az embereket, jelenleg itt él a legtöbb nem európai származású külföldi. A foglalkoztatottak száma magas, alacsonyabb az átlagéletkor és magasabb az iskolai végzettség, ezértelsősorban a gazdaságilag aktív, magasan kvalifikált külföldi állampolgárok telepednek le a főváros közelében. Az elmúlt tíz év során Budapest globálisan is migrációs célterületté vált. A NAV adatai alapján a személyi jövedelembevallást 
készítő külföldi állampolgárok (a külföldön született magyar állampolgárokra vonatkozóan nem áll rendelkezésre adat) aránya a teljes lakónépességhez képest közel 2\%, mellyel ők adják a jövedelemadó több mint 3\%-át. Közép-Magyarországon ezek az arányok 5\%-nál is magasabbak.

Három térséget emelhetünk ki migrációs szempontból, melyben általánosan és tartósan nagyobb számban és arányban vannak jelen a vizsgált vándorlási csoportok: Közép-Magyarországot, a határmenti járásokat és a Balaton térségét.

Budapest és Pest megye vonzza a legnagyobb távolságból az embereket, jelenleg itt él a legtöbb nem európai származású külföldi. A foglalkoztatottak száma magas, alacsonyabb az átlagéletkor és magasabb az iskolai végzettség, ezértelsősorban a gazdaságilag aktív, magasan kvalifikált külföldi állampolgárok telepednek le a főváros közelében. Az elmúlt tíz év során Budapest globálisan is migrációs célterületté vált. A NAV adatai alapján a személyi jövedelembevallást készitő külföldi állampolgárok (a külföldön született magyar állampolgárokra vonatkozóan nem áll rendelkezésre adat) aránya a teljes lakónépességhez képest közel 2\%, mellyel ők adják a jövedelemadó több mint 3\%-át. Közép-Magyarországon ezek az arányok 5\%-nál is magasabbak.

Magyarországon, ahol a külföldi állampolgárok legnagyobb része a szomszédos országokból érkezik, a külföldi kötődésű népesség területi megoszlásában meghatározó a célterületek elhelyezkedése is. Az új lakóhely megválasztásában tehát a gazdasági centrumterületek mellett a határmenti térségek is fontos szerepet játszanak, ahol főként a határ másik oldaláról érkezők telepednek le.

A Balaton térségét főként a német, osztrák, holland és svájci nyugdijasok, magasabb életkorúak választják új lakóhelynek a nyugdijak jobb vásárlóerejének kihasználása, illetve a rekreációs lehetőségek és a természeti értékek miatt. Sok esetben a külföldiek már a migrációt megelőzően turistaként (Kincses et al., 2014) részletes információval rendelkeznek a célterületekről. Az időskorú migráció volumene jelentősen növekedett a vizsgált időszakban. 
6. ábra: Külföldi kötődésü népesség 100 lakosra vonatkozó aránya

Proportion of foreign-born population per 100 inhabitants
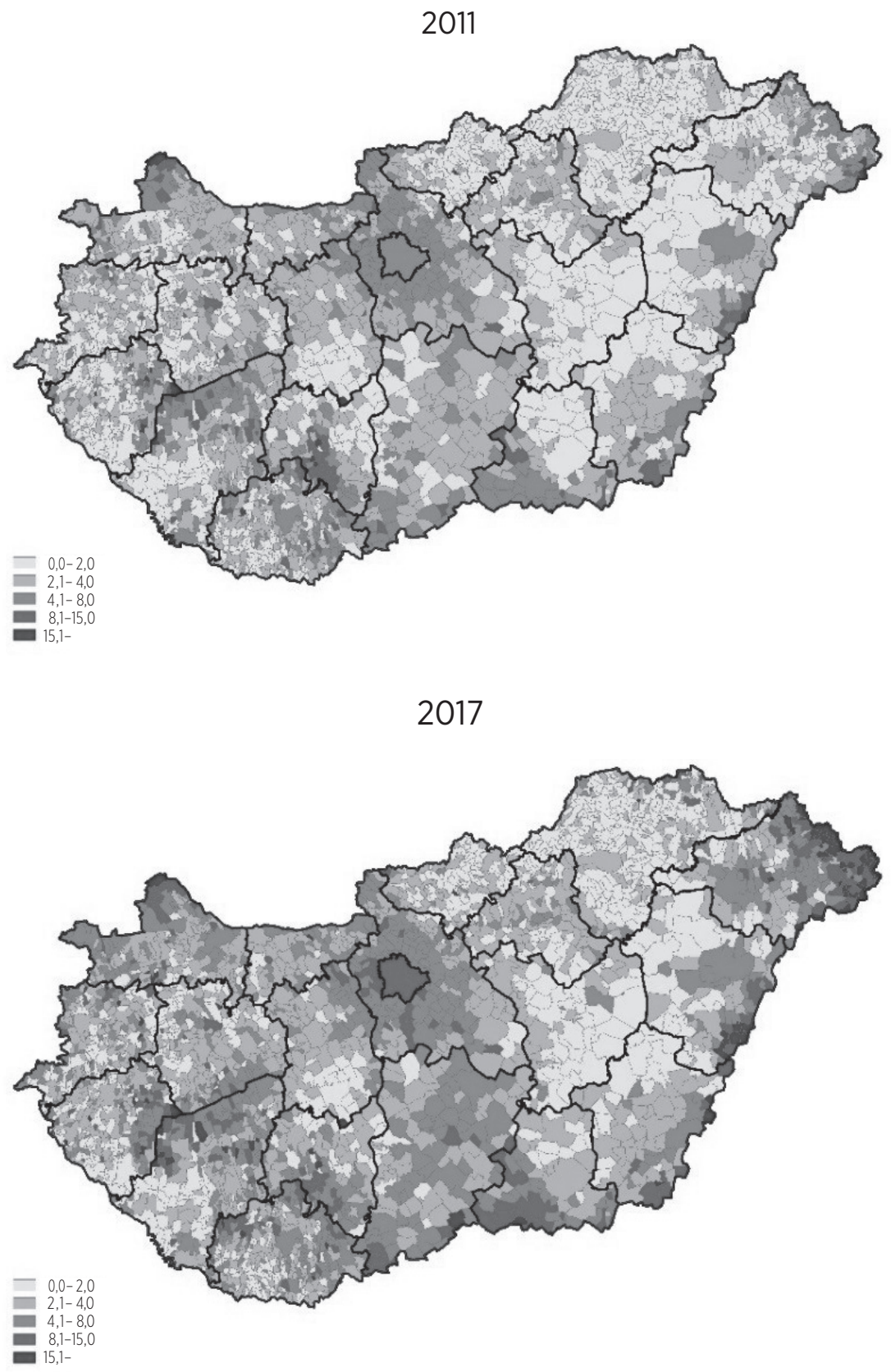

Forrás: Saját kalkuláció a BM és a KSH adatok alapján. 
7. ábra: Magyarország települései a legtöbb ott élő külföldi állampolgár szerint, 2017* The settlements of Hungary by the most foreign living citizens, 2017

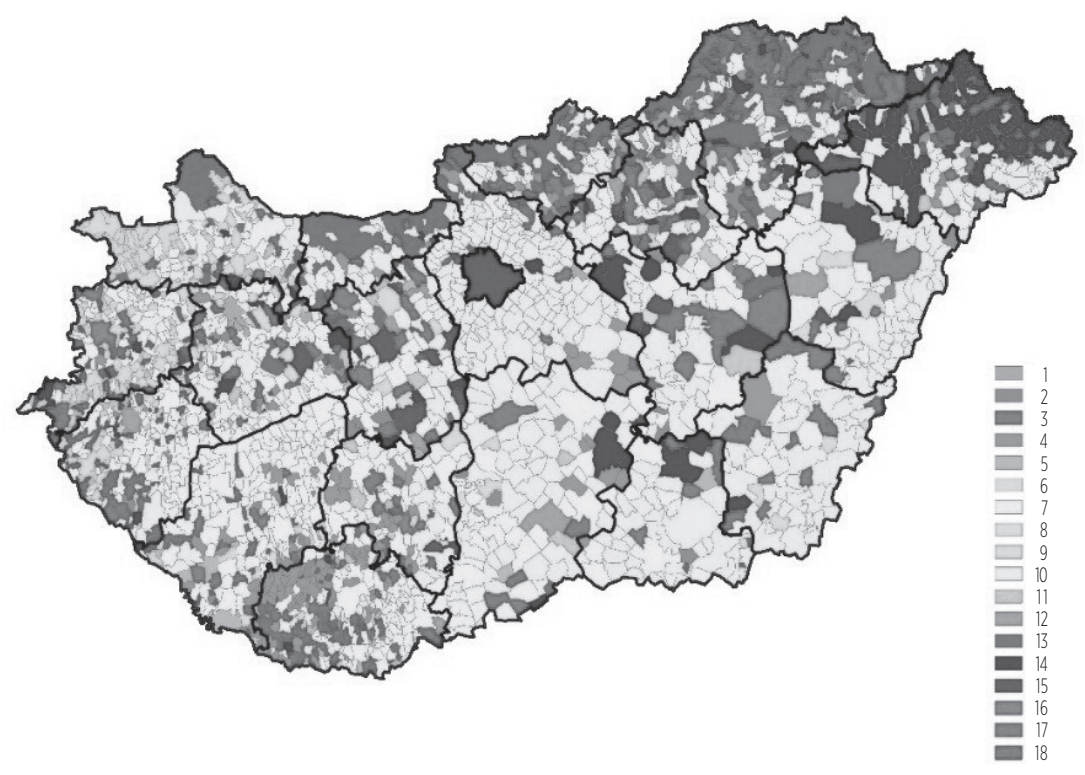

* 1 = amerikai; 2 = angol; 3 = belga; 4 = holland; 5 = horvát; 6 = lengyel; 7 = német; 8 = olasz; 9 = osztrák; 10 = román; 11 = svájci; 12 = szerb; 13 = szlovák; 14 = ukrán; 15 = kínai; 16 = orosz; 17 = egyéb; 18 = nincs külföldi Forrás: Saját kalkuláció a BM és a KSH adatok alapján.

\section{A MAGYARORSZÁGOT ÉRINTŐ NEMZETKÖZI VÁNDORLÁS KÁRPÁT-MEDENCEI FORRÁSTERÜLETEI}

\section{A migrációs forrásterületek meghatározása}

Az elvándorlások hatásainak vizsgálatában nem releváns, hogy valaki külföldi, illetve magyar állampolgárként él Magyarországon, így a továbbiakban együttesen kezelem a külföldi kötődésű népességet. A migrációs folyamatokat az eredeti (román, ukrán, szerb stb.), születéskori lakóhely és a vándorlók demográfiai, szociológiai és munkaerő-piaci változói szerint elemeztem. Minden esetben az általam tanulmányozott területi szint a megyei (NUTS3), mely a legtöbb szomszédos országra rendelkezésre áll. Azonban Ukrajna kivételt képez, esetükben nem létezik effajta osztályozás, mivel az „oblaszty” integráltabb, a „rajon” pedig részletesebb a vizsgált szintnél (Mezencev, 2010). Ám Ukrajnán belül leginkább 
Kárpátalja bír kitüntetett szereppel (hiszen az Ukrajnából érkezők döntő többsége innen származik), a finomabb beosztást alkalmaztam.

A szomszédos országokból érkező, Magyarországon élő külföldi kötődésű népesség száma 2017-ben 352506 fő volt. Közülük 7131 fő már Magyarországon született és további 560 fő nem az állampolgárságuknak megfelelő országban látta meg a napvilágot (pl: Németországban született román állampolgárok, vagy Svédországban született szerb állampolgárok). Tehát összesen 344815 olyan ember élt 2017-ben Magyarországon, akik a szomszédos országok valamelyikében született (nemzetiségi hovatartozástól függetlenül). Ez 2011-hez képest 24\%-os növekedést jelent.

2011. január 1-jén a Magyarországon élő, külföldön született népesség közül legtöbben Maros (27 879 fő), Bihar (27 374 fö), Hargita (26 439 fő), Kolozs (21 667 fő), Szatmár (17 102 fő) megyékben, a Nyitrai kerületben (13 742 fő), Kovászna megyében (10 821 fő), Beregszászi járásban (9 301 fő), az Észak-Bácskai (8 877 fő) körzetben, az Ungvári járásban (7 958 fő) és az Észak-Bánsági (7 668 fő) körzetekben születtek. Ezek azok a romániai, kárpátaljai, vajdasági és felvidéki területek, ahol a magyar nemzetiségüek aránya magas (Kapitány, 2015).

2017-re azonban az öt legnagyobb kibocsátó erdélyi megyének csak a sorrendje változott meg (Hargita 35613 fő, Maros 32433 fö, Bihar 31587 fő, Szatmár 20075 fő, Kolozs 19540 fő). A többi nagyobb forrásterület: Beregszászi járás (19 429 fő), Kovászna megye (17 021 fő), Észak-Bácskai körzet (12 769 fő), Ungvári járás (12 410 fő), Észak-Bánáti körzet (11 687 fő), Nagyszőlősi járás (11 628 fő) és a Nyitrai kerület (10 286 fő $)^{6}$.

Arányaiban nagyobb változások csak a kisebb kibocsátó területeken voltak, Ausztriában, Szlovéniában és Koszovóban. A nagyobb forrástérségekből Kárpátalja (Nagyszőlősi járás: 259\%, Beregszászi járás: 209\%, Munkácsi járás: 177\%, Huszti járás: 159\%, Ungvári járás: 156\%, Técsői járás: 131\%), valamint Bákó (243\%) és Kovászna (157\%) megyék kibocsátó szerepe erősödött meg a leginkább a vizsgált évek alatt.

A további, részletesebb vizsgálatokhoz földrajzi szempont alapján rendeztem csoportokba a környező országok régióit. Románia megyéit három részre osztottam. Az első csoportba a határhoz közel eső (lényegében Partium és Bánság) megyék (Arad, Bihar, Krassó-Szörény, Máramaros, Szilágy, Szatmár, Temes), a másodikba az erdélyi térségek (Fehér, Beszterce-Naszód, Brassó, Kolozs, Kovászna, Hargita, Maros, Hunyad, Szeben), a harmadikba az egyéb területek tartoztak.

\footnotetext{
${ }^{6}$ A tanulmány 3. táblázata tartalmazza a Kárpát-medencében élő magyar lakosság számait megyei bontásban.
} 
8. ábra: Magyarországon élő, szomszédos országok külföldi kötődésü népessége születési régiók szerint $^{*}$

The foreign-born population of neighboring countries who living in Hungary according to theirs regions of birth

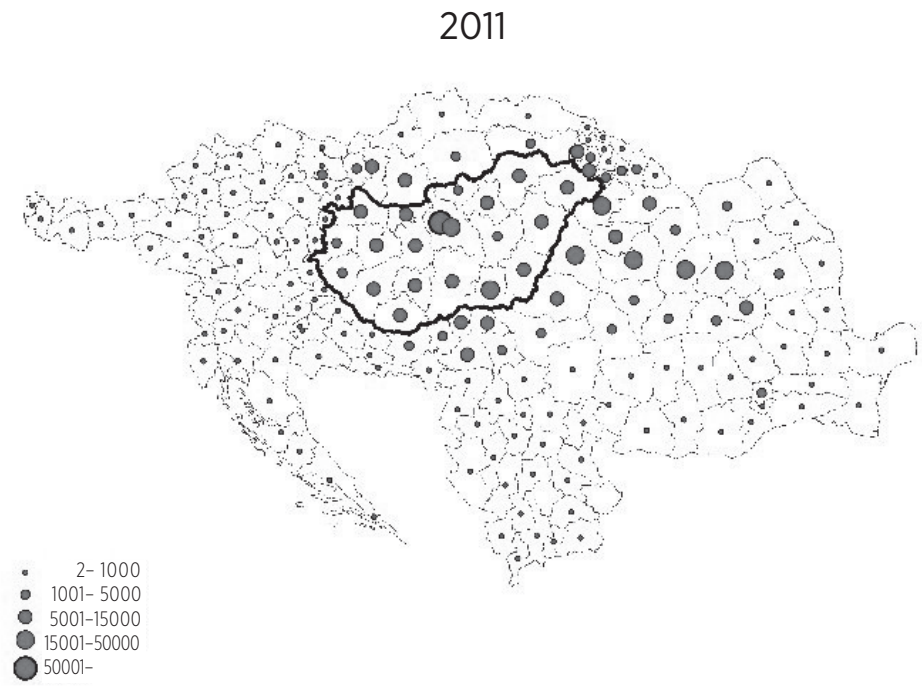

\section{7}

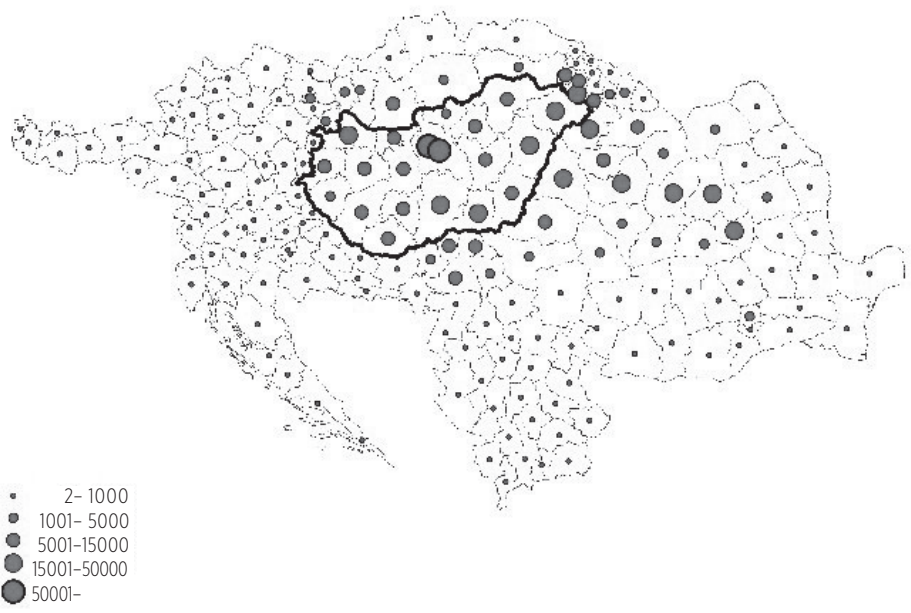

* A térképeken a szomszédos országokra a Magyarországon élő adott állampolgárok születési helyei, míg a magyar részeken az adott megyében élő, környező országokban születettek vannak feltüntetve (ezt a meggondolást alkalmaztam a dolgozat összes ezután következỏ térképén is).

Forrás: Saját kalkuláció a BM és a KSH adatok alapján. 
Romániához hasonlóan három csoportot különböztettem meg Ukrajna esetében is, teljes egészében, diszjunkt módon lefedve az ukrajnai településeket. Az első osztályba a határhoz közel eső Beregszászi, Munkácsi, Nagyszőlősi és Ungvári járásokat soroltam. Ez a terület a magyar Alföld szerves folytatásaként a Kárpátaljai-alföld, ezért itt vannak jelen legnagyobb létszámban és arányban magyarok Ukrajna területén (Kocsis et al., 2006). A második csoport a Kárpátalja hegyvidék területe, a főként ruszinok lakta Lemkó-Nagybereznai és Perecsenyi járások és Bojkóvidék - Szolyvai, Volóci, Ilosvai és Ökörmezői járások -, továbbá a magas természetes szaporulattal jellemezhető Hucul-vidék - Rahói járás - és a Máramarosi-medence - a Huszti és a Técsői járás. A csoporton belül a Felső-Tisza menti, máramarosi városok - Huszt, Visk, Técső, Aknaszlatina - jelentősebb magyar kisebbséggel bírnak. Míg a harmadik csoportot Ukrajna belső, Kárpátokon túli területei adják.

Szerbiát szintén három egységre bontottam. Az első kategóriába a határhoz közel eső észak-bácskai, észak-bánsági és nyugat-bácskai körzetek tartoztak, a másodikba a dél-bácskai, dél-bánsági, közép-bánsági és szerémségi területek, míg a harmadik csoportot az egyéb körzetek, azaz a Vajdaságon kívüli szerb területek alkotják.

A szlovákiai lakóhelyeket két részre osztottam. Az elsőbe a Magyarországgal határos Besztercebányai, Nyitrai, Nagyszombati és Kassai körzetek, a másodikba pedig a többi (Eperjesi, Pozsonyi, Trencsényi, Zsolnai) területek tartoznak.

Ausztriában három kategóriát különböztettem meg. Az első Burgenland, a második a határhoz közel eső Bécsi, Alsó-Ausztriai és Stájerországi régiók, a harmadik pedig a többi (Tirol, Salzburg, Voralberg, Karintia és Felső-Ausztria) terület.

Horvátország, illetve Szlovénia esetén két-két kategóriát alkalmaztam. Horvátországban az első csoportba a határmenti megyéket (Eszék-Baranya, Kapronca-Körös, Muraköz, Verőce-Drávamente, Vukovár-Szerémség), a másodikba pedig a többi területet soroltam. Szlovéniában az első csoportba a határmenti Muramenti megyét, míg a másodikba a többi térséget osztottam.

\section{A külföldi kötődésű népesség demográfiai, munkaerő-piaci és szociológiai jellemzőinek kapcsolata a születési térségekkel}

Magyarországon a nemzetközi vándorlók nemek közötti aránya nőtöbbletet mutat (Gödri, 2011), azonban a ráta nem egységes forrásrégiók szerint, erős területi különbségek fedezhetők fel. A Magyarországgal szomszédos megyékben születettekre stabil, 55-56\%-os a nők részaránya. A Romániából, Szlovákiából, 
Ukrajnából érkezőkre egyaránt jellemző a nőtöbblet, ami Dél-Szlovákia esetén közel kétharmados. Szerbiára és Szlovéniára enyhe férfitöbblet jellemző, noha a Vajdaságból érkezők esetén női felülreprezentáltság, míg a Szerbia többi részéről érkezőkre erős férfitöbbletet mérhetünk. A horvát és az osztrák születésű nemzetközi vándorlók esetén kiegyenlített a ráta.

A 2011-es és 2017-es adatok egyaránt megerősítik, hogy a Magyarországon élő külföldi állampolgárok átlagéletkora Szlovákia nyugati részéről, Szerbia déli területeiről és Románia Erdélyen kívüli térségeiből származók esetén a legmagasabb, több esetben az 50 éves átlagot is jóval túlszárnyalva.

A 65 év felettiek aránya Szlovákiából, Románia Erdélyen túli részéből és Ausztria nyugati tartományaiból érkezőknél a legmagasabb. Ez utóbbi oka a nyugdijak vásárlóerejének jobb kihasználása, valamint a kedvezőbb természeti környezet keresése (Hévíz) (Illés, 2008). A többi eset mögött a régebben bevándorlók idősödése, illetve a Magyarországon elérhető magasabb szintű szociális és egészségügyi ellátás állhatnak. Ukrajnából érkezett, 65 év feletti népesség számossága a 8000 főt is meghaladja, így a magyar jogszabályok alapján a magyar nyugdíjszámítás szerint kapnak nyugdíjat, ami magasabb, mint ami Ukrajnában megilletné őket (Gellérné és Szigeti, 2005)ํ. Más kutatásokból (Tátrai et al., 2018) valószínűsíthető, hogy e szubpopuláció egy része mindkét országban rendelkezik bejelentett lakóhellyel, de életvitelszerűen továbbra is Kárpátalján él.

A fiatalok nagyrésze Ausztriából, Ukrajnából és Szlovéniából érkeznek főként, mely részben a tanulási célú migrációval magyarázható. Ausztria esetén fontos megemlíteni, hogy a statisztika részben olyan külföldön született magyar gyermekek bevándorlását detektálja, akiknek a családja korábban kivándorolt az országból, de később kiskorú gyermekükkel hazatértek.

A munkaképes korú 25-64 éves korosztály aránya Kárpátaljáról, Erdélyből és Észak-Vajdaságból érkezőkre a legmagasabb. Az országhatár közelében születettek között több a nyugdíjas korú és a fiatal, míg a távolabbi térségekben születettekre jóval jellemzőbb a munkavállalási kor.

\footnotetext{
${ }^{7}$ Magyarországnak területi elven megkötött, érvényes és müködő kétoldalú szociálpolitikai egyezménye van az 1960-as évek elejétől több volt szocialista országgal. Az egyezmények akkor alkalmazhatók, ha az érintett természetes személy állandó lakóhelye valamelyik szerződő állam területén van. Az ellátásokat mindkét fél területén szerzett szolgálati idő egybeszámításával annak az országnak a társadalombiztosítási szerve állapítja meg a saját belső jogszabályai alapján, amelynek területén a jogosult állandó lakóhelye van. Az egyezmények azon a maga idejében reális feltételezésen alapultak, hogy az országok között alacsony szintű és hozzávetőlegesen egyenlő nagyságú nemzetközi vándorlások lesznek. Az egyes államok közel azonos szintű szolgáltatást fognak nyújtani, így a szerződő államok terhei nagyjából kiegyenlítődnek. Ez a feltételezés már a megkötés idejében sem igazolódott be, az 1990-es évektől pedig csak tovább fokozódott az arányeltolódás Magyarország terhére (Gellérné és Szigeti, 2005).
} 
9. ábra: Magyarországon élő, szomszédos országok külföldi kötődésü népessége születési régiók és átlagéletkorok szerint

The foreign-born population of neighboring countries who living in Hungary according to theirs regions of birth and their average age
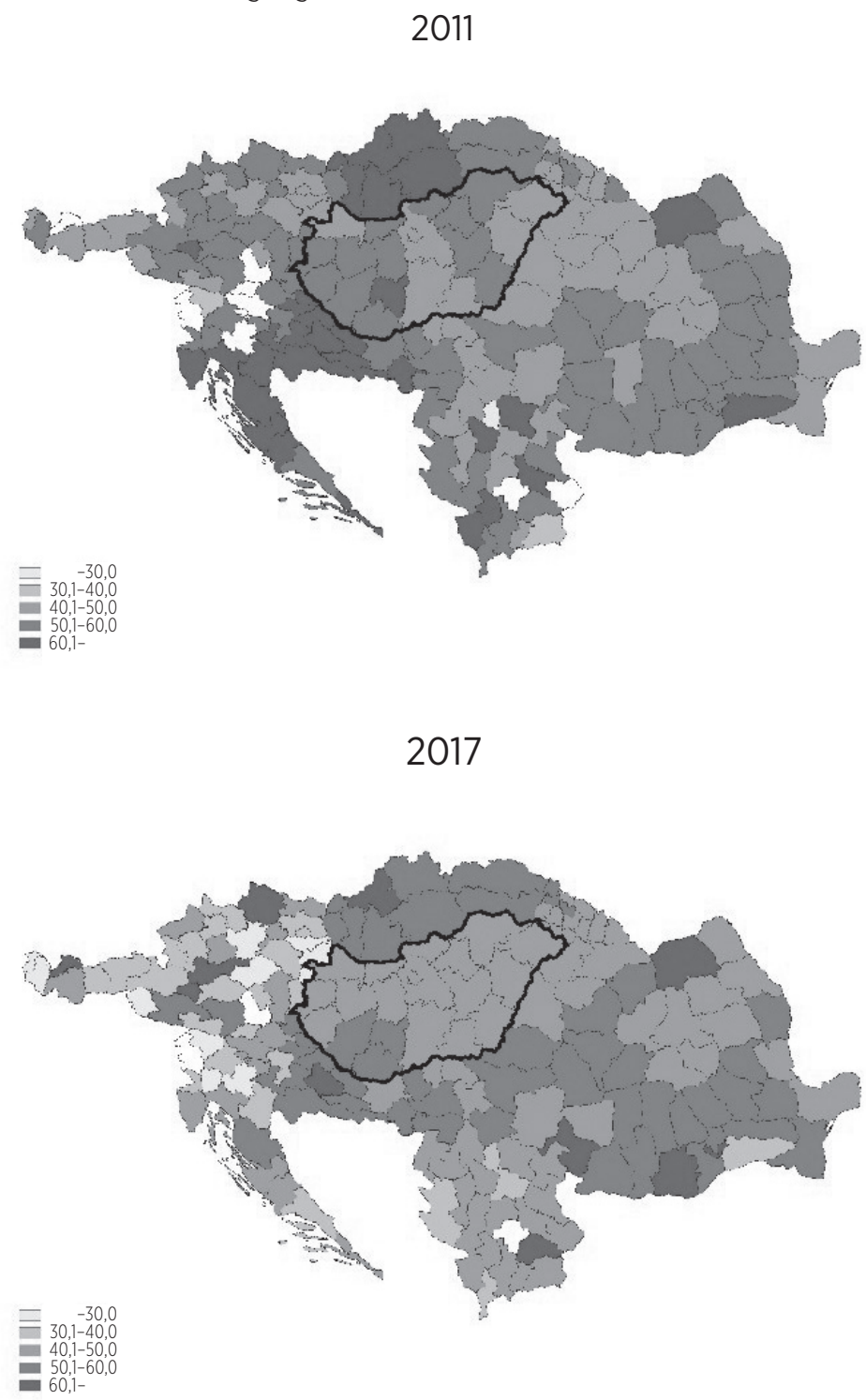

Forrás: Saját kalkuláció a BM és a KSH adatok alapján. 
10. ábra: Magyarországon élö, szomszédos országok külföldi kötődésü népesség korcsoportok szerinti megoszlása születési térségenként, 2017

The distribution of foreign-born population of neighboring countries who living in Hungary according to theirs age group and regions of birth

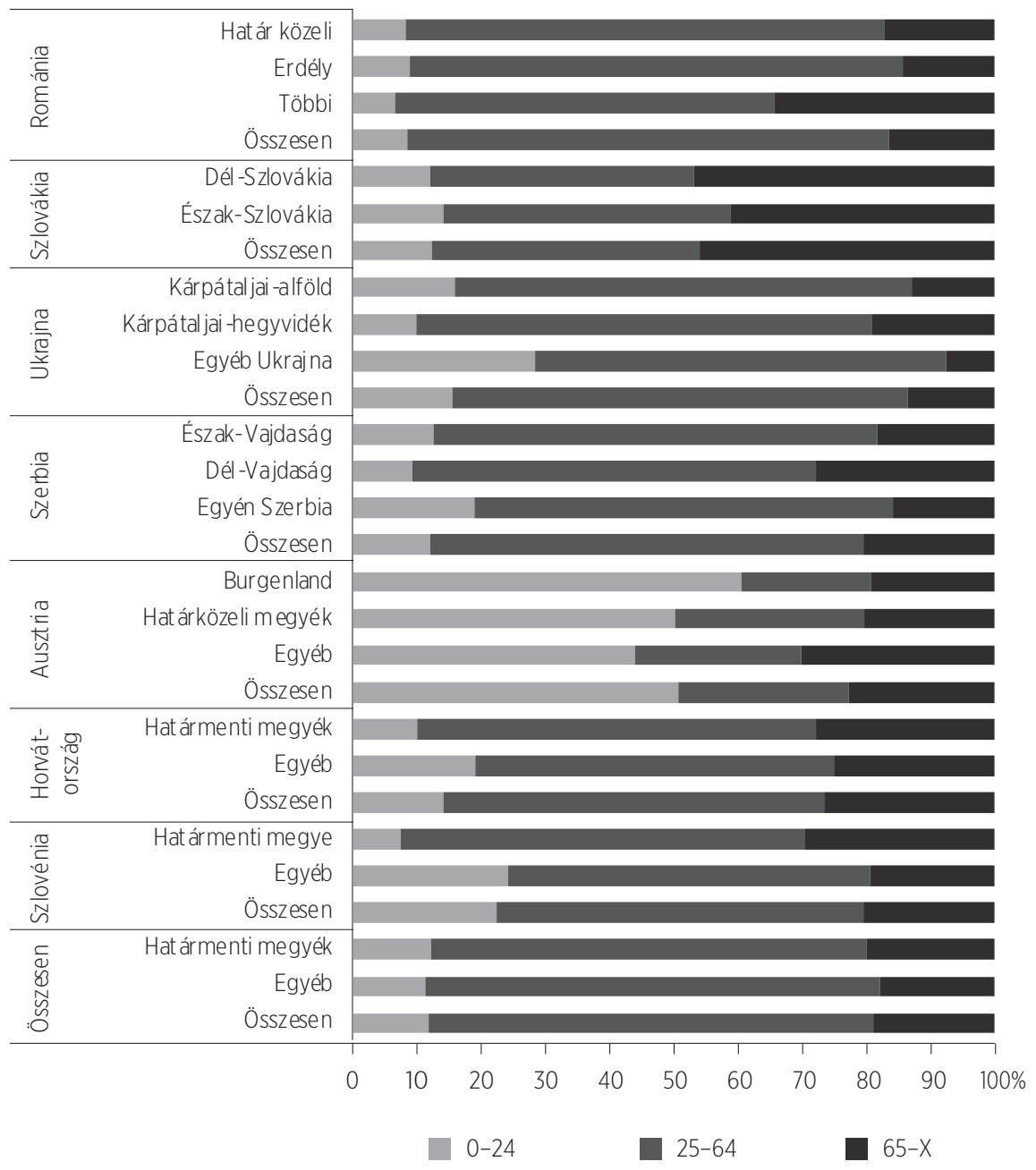

Forrás: Saját kalkuláció a BM és a KSH adatok alapján.

A jelenséget családtípusok szerint vizsgálva azt láthatjuk, hogy a gyermek nélkül élő háztartások száma visszaszorulóban van a vándorlók átlagéletkorának csökkenésével, 2017-re a gyerekes családokban élő külföldi kötődésű népesség 
aránya 61\%-ra emelkedett, azaz a családegyesítés, a családok együtt történő vándorlása fokozódott a vizsgált években. A nagyobb arányú időskorúak miatt a Szlovákiából érkezők általában gyerek nélküli háztartásban élnek.

11. ábra: Magyarországon élő, szomszédos országok külföldi kötődésü népessége születési régió és a gyereket nevelő háztartásban élők aránya szerint The foreign-born population of neighboring countries who living in Hungary according to theirs regions of birth and the rate of parenting household
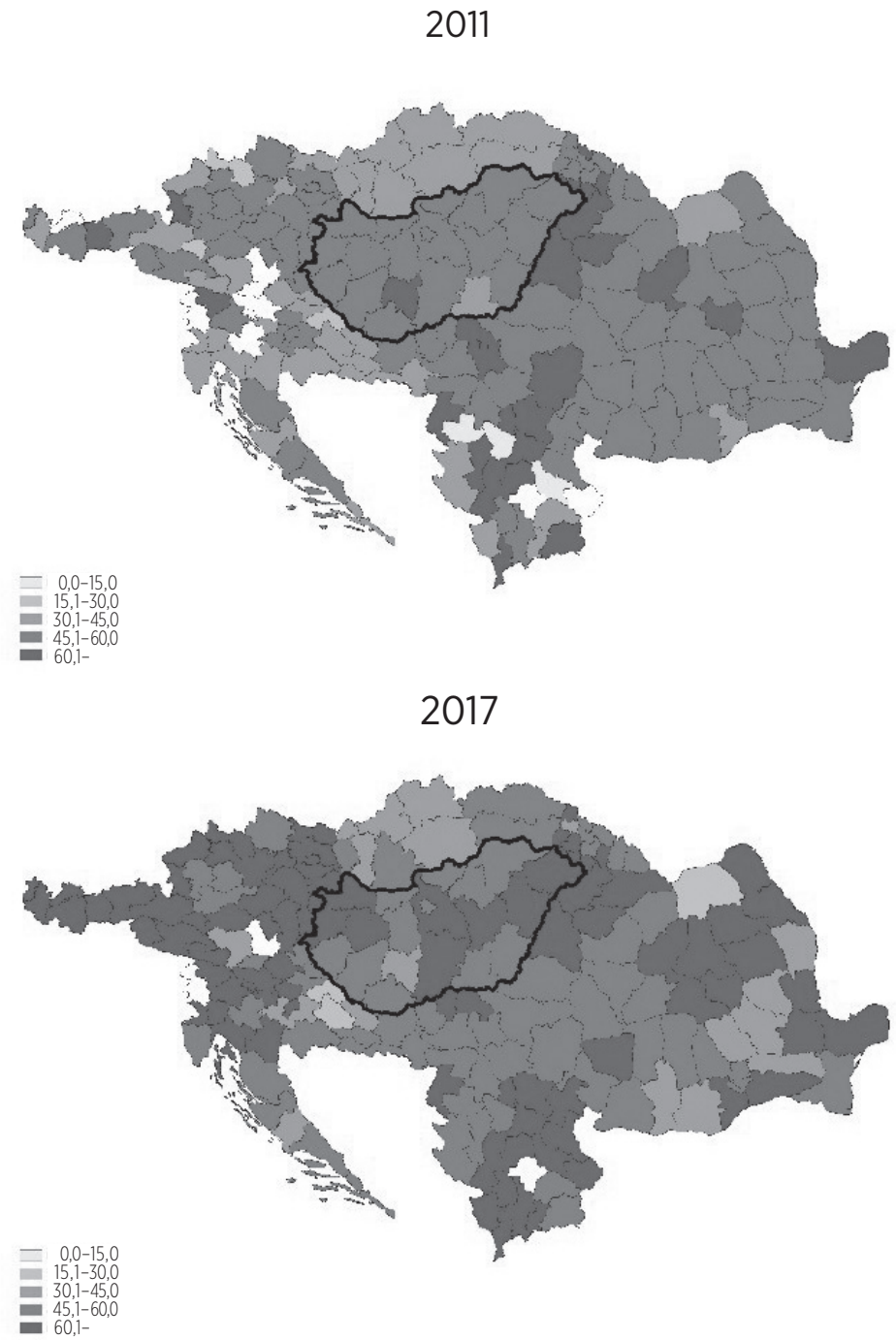

Forrás: Saját kalkuláció a BM és a KSH adatok alapján. 
12. ábra: Magyarországon élő, szomszédos országok külföldi kötődésü népessége családtípusok szerint születési térségenként, 2017

The foreign-born population of neighboring countries who living in Hungary according to theirs family type of regions of birth, 2017

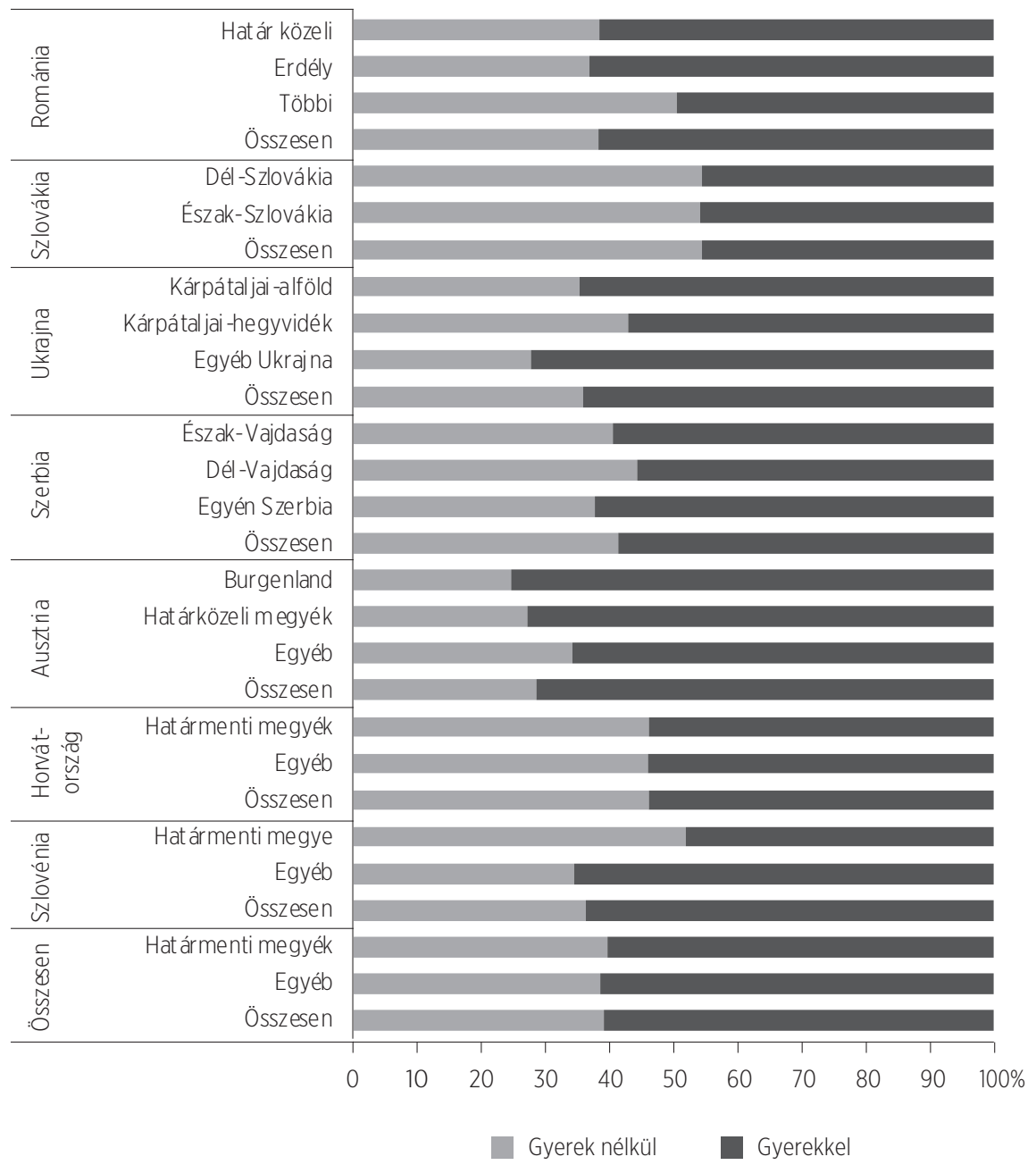

Forrás: Saját kalkuláció a BM és a KSH adatok alapján.

A nemzetközi migráció hazai jellegzetessége, hogy a bevándorló népesség nagy része magyar nemzetiségü, illetve anyanyelvű. A határon túl nyúló nyelvi, kulturális kapcsolatok erőssége elsősorban az I. és II. világháborút lezáró békeszerződések következménye. Ez a determinizmus folyamatosan, de viszonylag 
lassan csökken, melynek alapvető oka, hogy a magyarok aránya egyre kevesebb a bevándorló népességen belül.

13. ábra: Magyarországon élö, szomszédos országok külföldi kötődésủ népessége születési régiók és a magyar anyagnyelvüek aránya szerint

The foreign-born population of neighboring countries who living in Hungary according to theirs regions of birth and the rate of native Hungarians
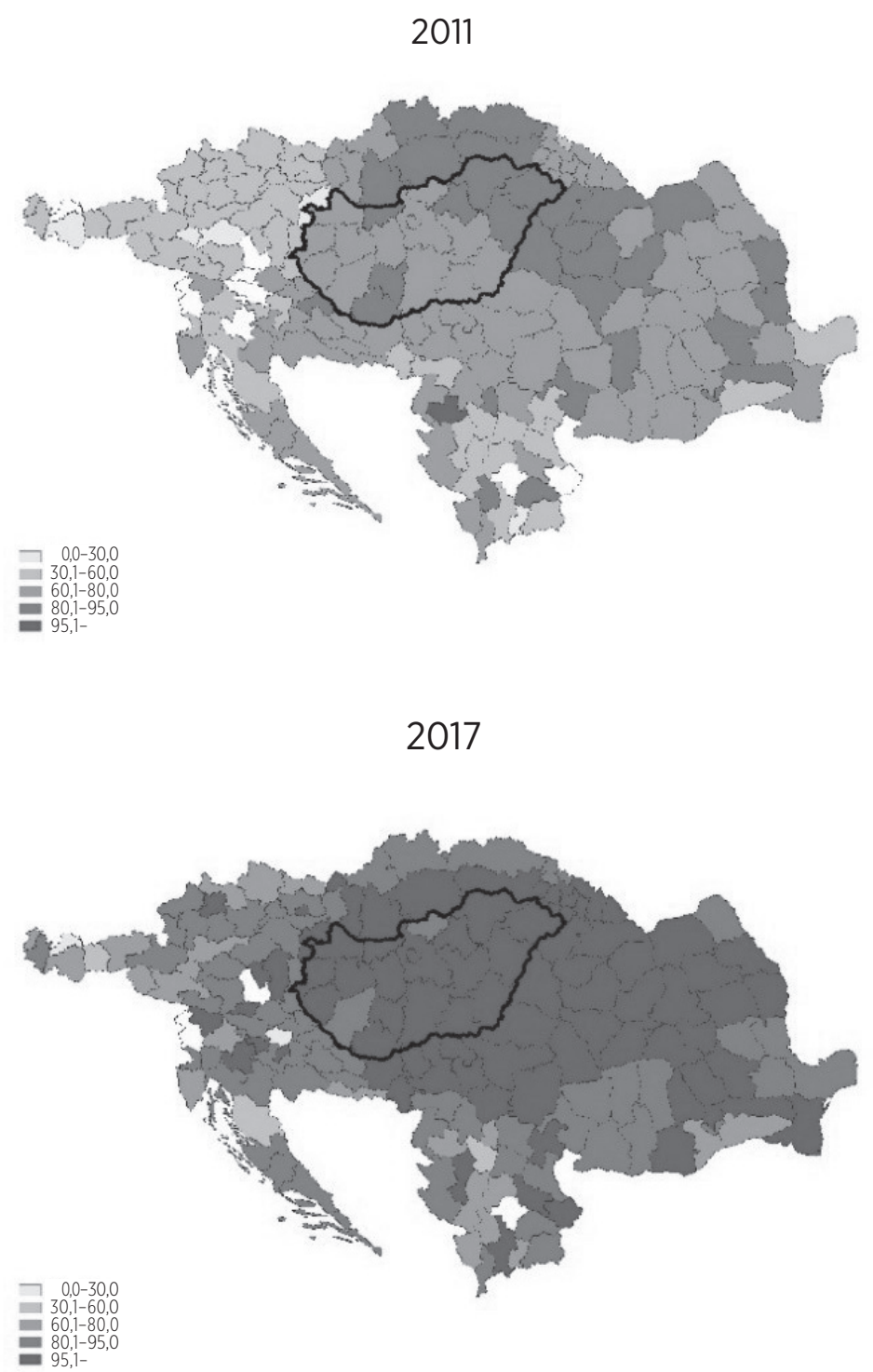

Forrás: Saját kalkuláció a BM és a KSH adatok alapján. 
14. ábra: Magyarországon élő, szomszédos országok külföldi kötődésü népessége anyanye/v szerint születési térségenként, 2017

The foreign-born population of neighboring countries who living in Hungary according to theirs mother tongue by regions of birth, 2017

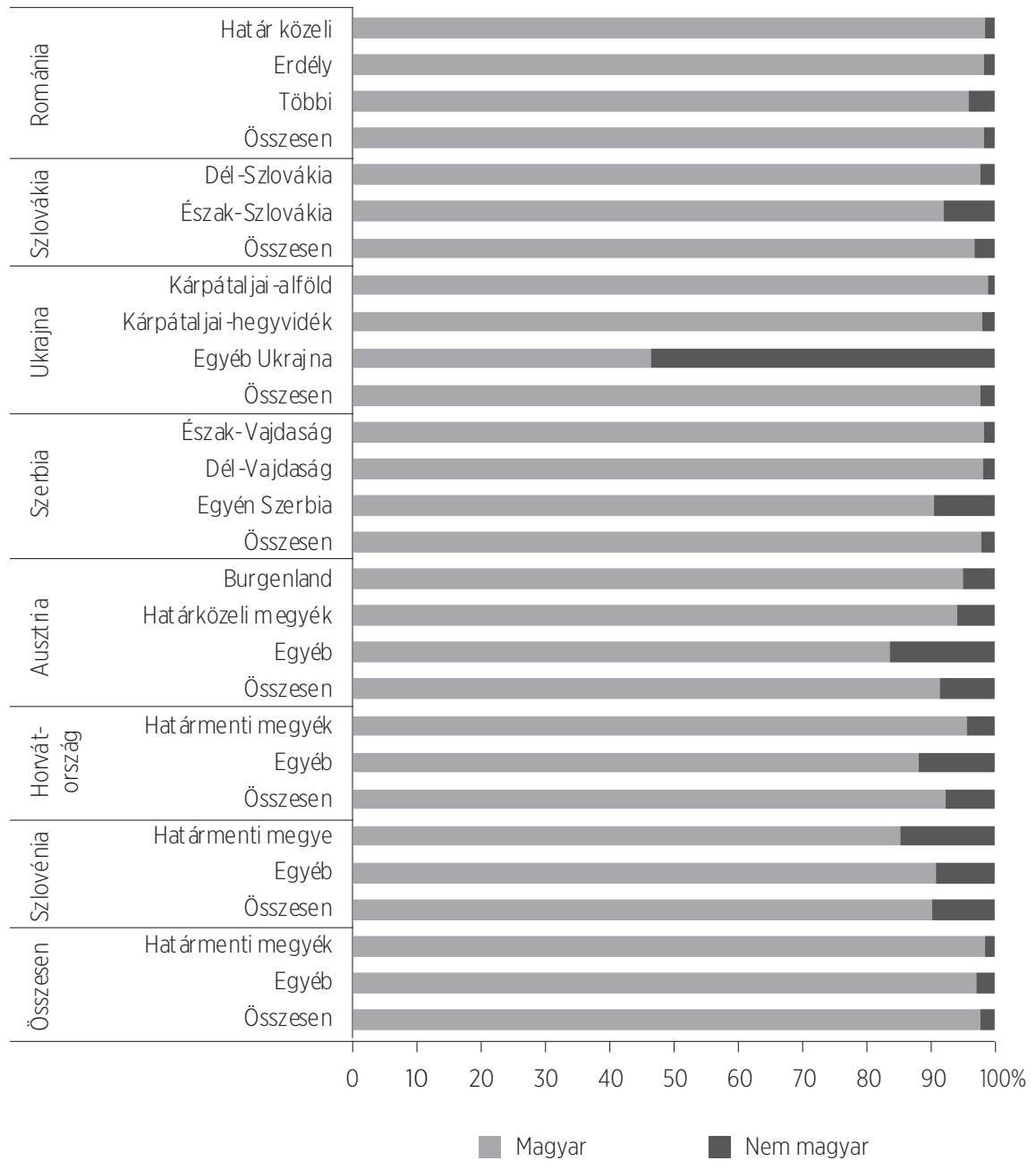

Forrás: Saját kalkuláció a BM és a KSH adatok alapján.

2011-ben önbevallás alapján 14\% volt nem magyar anyanyelvű a Kárpátmedence országaiból érkezők aránya, ez 2017-ben 3\% körül alakult. A változás mögött részben a nem magyar etnikumúak asszimilációja is 
állhat ${ }^{8}$, mely jelenség mögött az 1918 előtti idők demográfiai folyamatait ismerhetjük fel. A nem magyar anyanyelvúek aránya Ukrajna Kárpátokon túli területeiről, Észak-Szlovákiából, Szerbia Vajdaságon kívüli részeiről, valamint Ausztriából, Horvátországból és Szlovéniából érkezőkre magasabb, ahol a magyarok arányai eleve kisebbek. Ukrajna esetén tapasztalható kiugró érték összefüggésbe hozható a 2014 óta elhúzódó orosz-ukrán konfliktussal, a gazdasági, társadalmi krízissel és bizonytalansággal (Karácsonyi et al., 2014).

Magyarországon a bevándorlók átlagosan magasabb iskolai végzettségüek, mint a lakónépesség (Rédei, 2007), mely állitás hasonlóan igaz a szomszédos országok állampolgáraira is. 2011-ben Magyarországon a 25 éves vagy annál idősebb lakónépesség több mint fele rendelkezett legalább érettségivel, ez az arány a szomszédos országokból érkezőknél $68 \%$ volt. Az iskolai végzettségek folyamatosan emelkednek, miközben nincsenek nagy területi különbségek forrásrégiók szerint a végzettségek megoszlásában.

Mára részben megdőlni látszik az a több évtizedes szabály, hogy a migráció potenciális hatásterülete az iskolai végzettséggel növekszik (Rédei, 2007). Napjainkban ugyanis a nagyobb távolságú vándorlásban az alacsonyabb iskolai végzettségüek hasonló arányban vesznek részt, mint a kisebb távolságú mozgásokban.

Románia, Kárpátalja, Ausztria és Szlovákia esetén a születési hely határtól mért távolsága és az iskolai végzettségek között nem mutatható ki szignifikáns összefüggés, míg a többi szomszédos országra a határtól távolodva a felsőfokú végzettséggel rendelkező személyek aránya növekszik.

$A z$ iskolai végzettségnek meghatározó szerepe van a munkaerő-piaci jellemzőkre nézve is. A szomszédos országokban született, Magyarországon élő 25-64 éves lakosság foglalkoztatási rátája 79\% volt 2017-ben, vagyis a környező országok állampolgárainak nagyobb arányban van munkájuk, mint a lakónépességnek (75,1\%).

\footnotetext{
8 Az észak-erdélyi szórványban (és általában a trianoni határainkon kívüli országrészekben) élök nemzetiségi hovatartozásáról a legmegbízhatóbb adataink a ll. világháború előtti időkből származnak. 1941-ben ezeken a településeken 779829 fö élt, közülük 124 748-an vallották magukat magyarnak, 572 ezren románnak, közel 25 ezren németnek, míg 58 ezren egyéb nemzetiséghez tartoztak (Tóth, 1999). Jelenleg Magyarországon e 709 közül 47 településből érkeztek magyarok, legnagyobb számban Érmihályfalváról (1414-en), a Tóth Pál Péter által lehatárolt észak-erdélyi szórvány térségből összesen 4188-an. Ugyanakkor 14 olyan település is található a listán (30\%-a ezeknek a településeknek), ahonnan az érkező magyarok száma meghaladja az 1941-es települési magyar populációt. Ez az adat is azt a feltételezést erősíti meg, hogy a többes identitás, a magyarokhoz történő asszimiláció továbbra is élő jelenség a Kárpát-medencében.
} 
15. ábra: Magyarországon élő 25 év feletti, szomszédos országok külföldi kötődésü népessége felsőfokú iskolai végzettség és születési régiók szerint The foreign-born population of neighboring countries who living in Hungary (over 25 years) according to theirs university degree and regions of birth
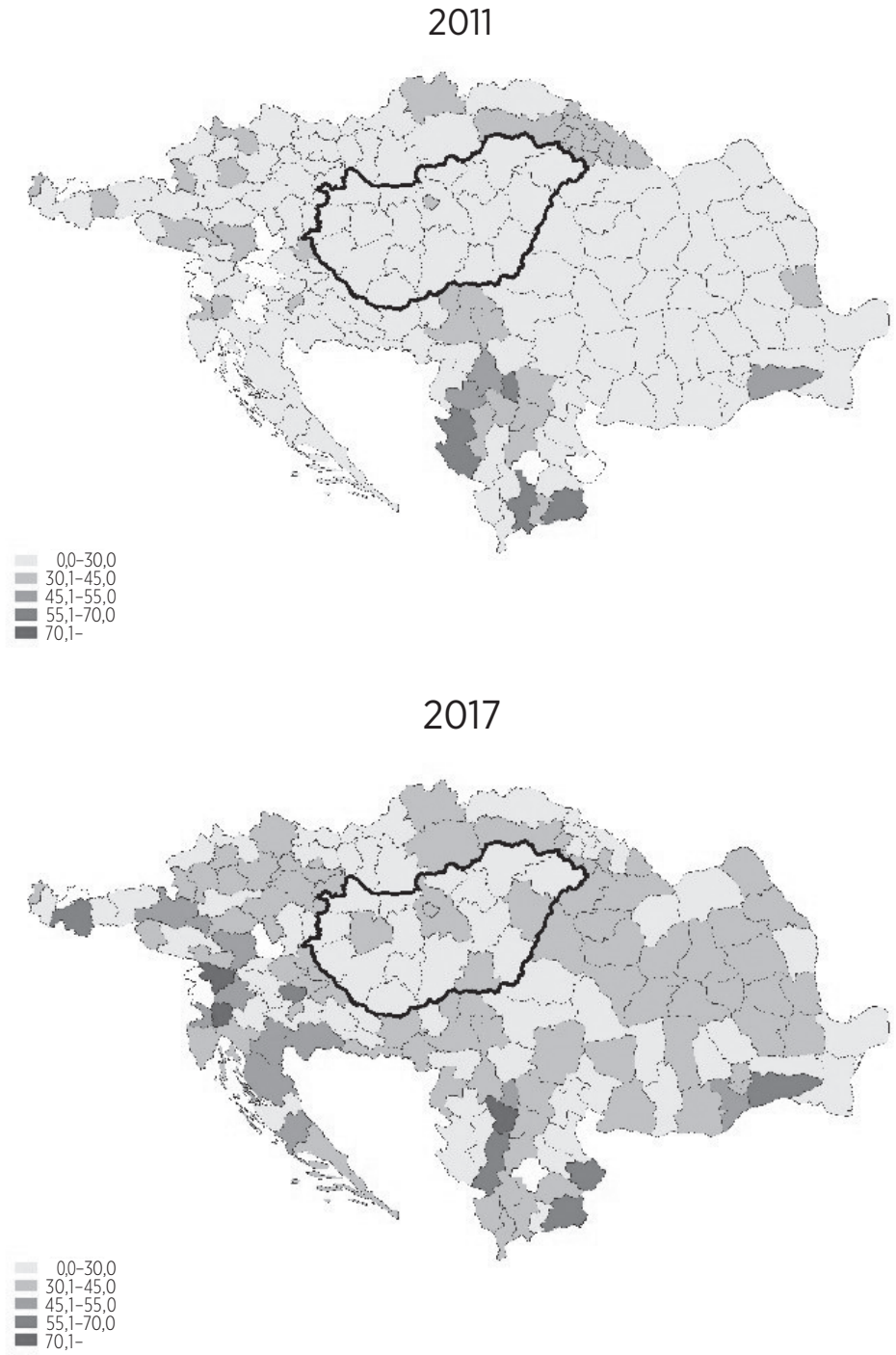

Forrás: Saját kalkuláció a BM és a KSH adatok alapján.

Születési régiók szerint a határtól távolabb eső szerb és román, és a határmenti horvát és szlovén régiókra a legmagasabbak a foglalkoztatottsági arányok, melyek részben az iskolai végzettségek magasabb értékeivel hozhatók összefüggésbe. Leg- 
magasabb az inaktívak aránya az Ausztriából és Ukrajna Kárpátalján kívüli területéről származók esetén. Ennek oka főként az, hogy sokan még diákok, illetve saját vagyonukból élnek, míg az utóbbi ország esetén többen még nem tudtak bekapcsolódni a munkaerő-piaci folyamatokba, illetve nem legálisan vannak foglalkoztatva.

16. ábra: Magyarországon élő 25 év feletti, szomszédos országok külföldi kötődésü népessége végzettség szerint születési térségenként, 2017

The foreign-born population of neighboring countries who living in Hungary (over 25 years) according to theirs education and regions of birth, 2017

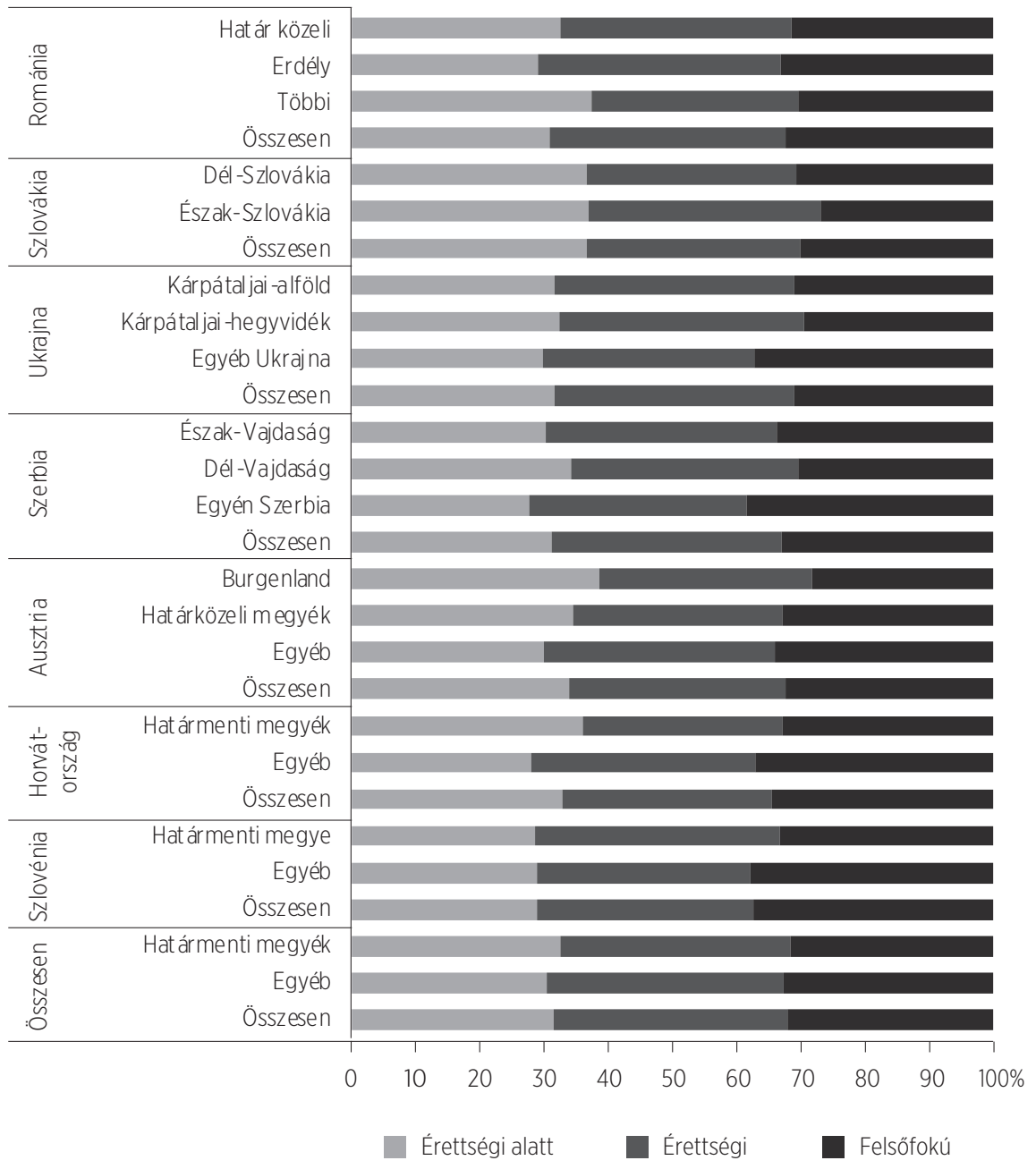

Forrás: Saját kalkuláció a BM és a KSH adatok alapján. 
17. ábra: Magyarországon élő 25-64 éves, szomszédos országok külföldi kötődésü népessége foglalkoztatottsági arányai és születési terület szerint The foreign-born population of neighboring countries aged 25-64 who living in Hungary by employment rates and area of birth
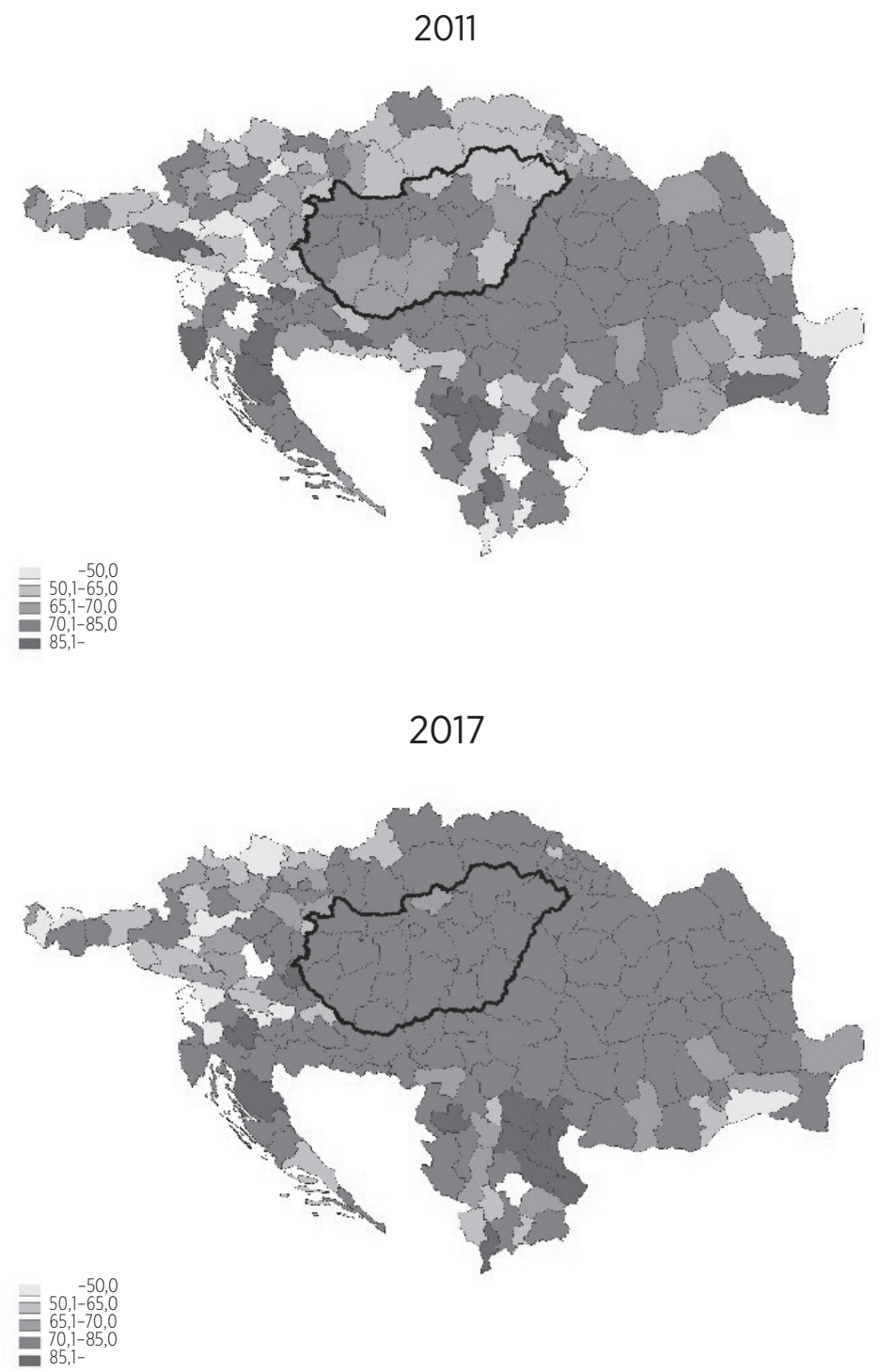

Forrás: Saját kalkuláció a BM és a KSH adatok alapján. 
18. ábra: Magyarországon élő 25 és 64 év közötti, szomszédos országok külföldi kötődésü népessége foglalkoztatottság szerint születési térségenként, 2017

The foreign-born population of neighboring countries aged 25-64 who living in Hungary by employment rates and area of birth, 2017

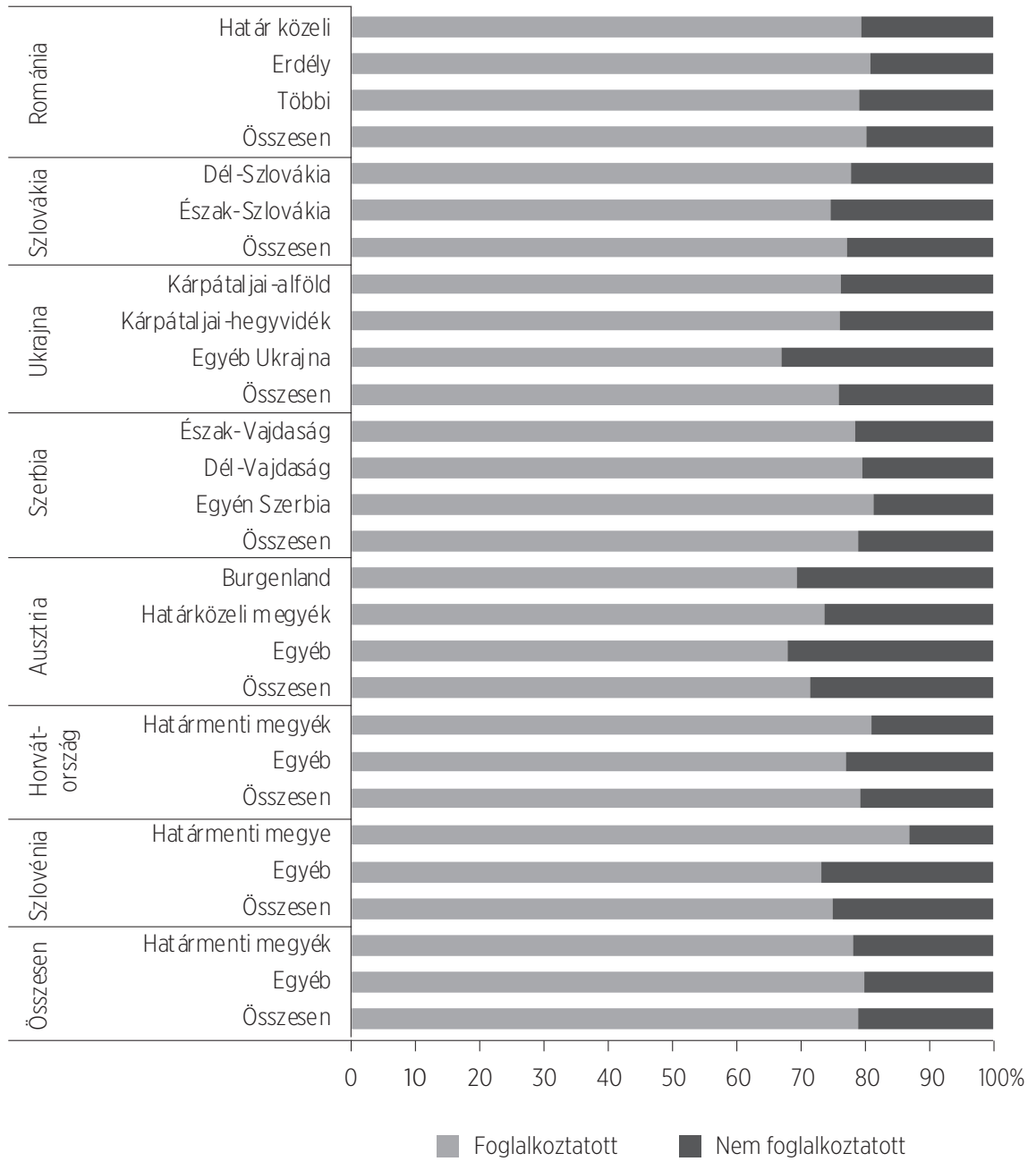

Forrás: Saját kalkuláció a BM és a KSH adatok alapján. 
19. ábra: Magyarországon élő 25-64 éves, szomszédos országok külföldi kötődésü népessége a legjellemzőbb foglalkozási föcsoport* és születési régiók szerint The foreign-born population of neighboring countries aged 25-64 who living in Hungary by the most typical job group and regions of birth

\section{1}

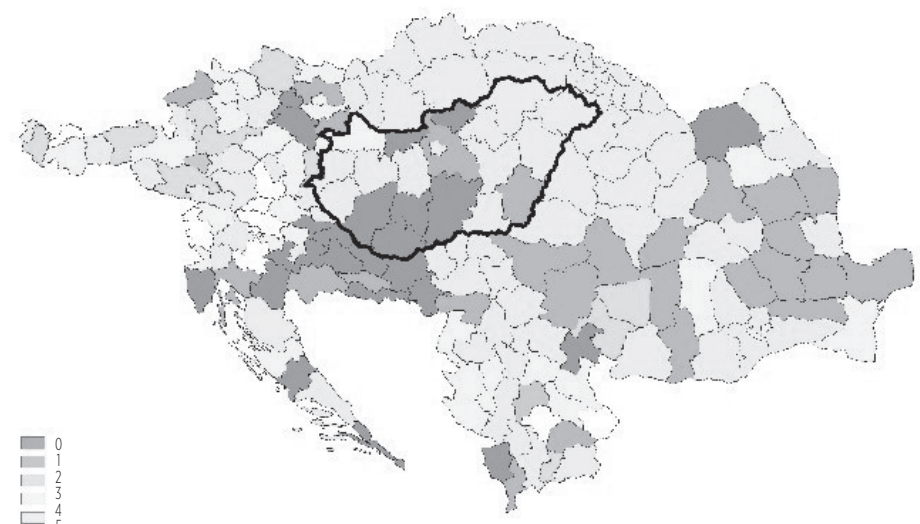

\section{7}

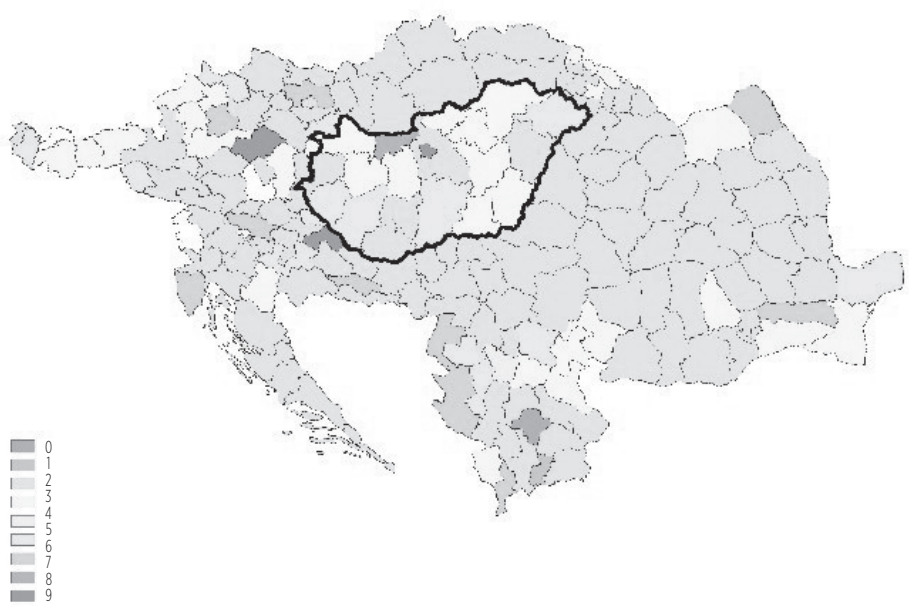

* 0. Főcsoport: Fegyveres szervek foglalkozásai; 1. Főcsoport: Gazdasági, igazgatási, érdek-képviseleti vezetők, törvényhozók; 2. Főcsoport: Felsőfokú képzettség önálló alkalmazását igénylő foglalkozások; 3. Főcsoport: Egyéb felsőfokú vagy középfokú képzettséget igénylő foglalkozások; 4. Főcsoport: Irodai és ügyviteli (ügyfélkapcsolati) foglalkozások; 5. Főcsoport: Kereskedelmi és szolgáltatási foglalkozások; 6. Főcsoport: Mezőgazdasági és erdőgazdálkodási foglalkozások; 7. Főcsoport: Ipari és építőipari foglalkozások; 8. Főcsoport: Gépkezelők, összeszerelők, jármüvezetők; 9. Főcsoport: Szakképzettséget nem igénylő (egyszerű) foglalkozások.

Forrás: Saját kalkuláció a BM és a KSH adatok alapján. 
20. ábra: Magyarországon élő 25-64 éves, szomszédos országok külföldi kötődésű népessége foglalkozási föcsoport szerint születési térségenként, 2017

The foreign-born population of neighboring countries aged 25-64 who living in Hungary by occupational groups and regions of birth, 2017

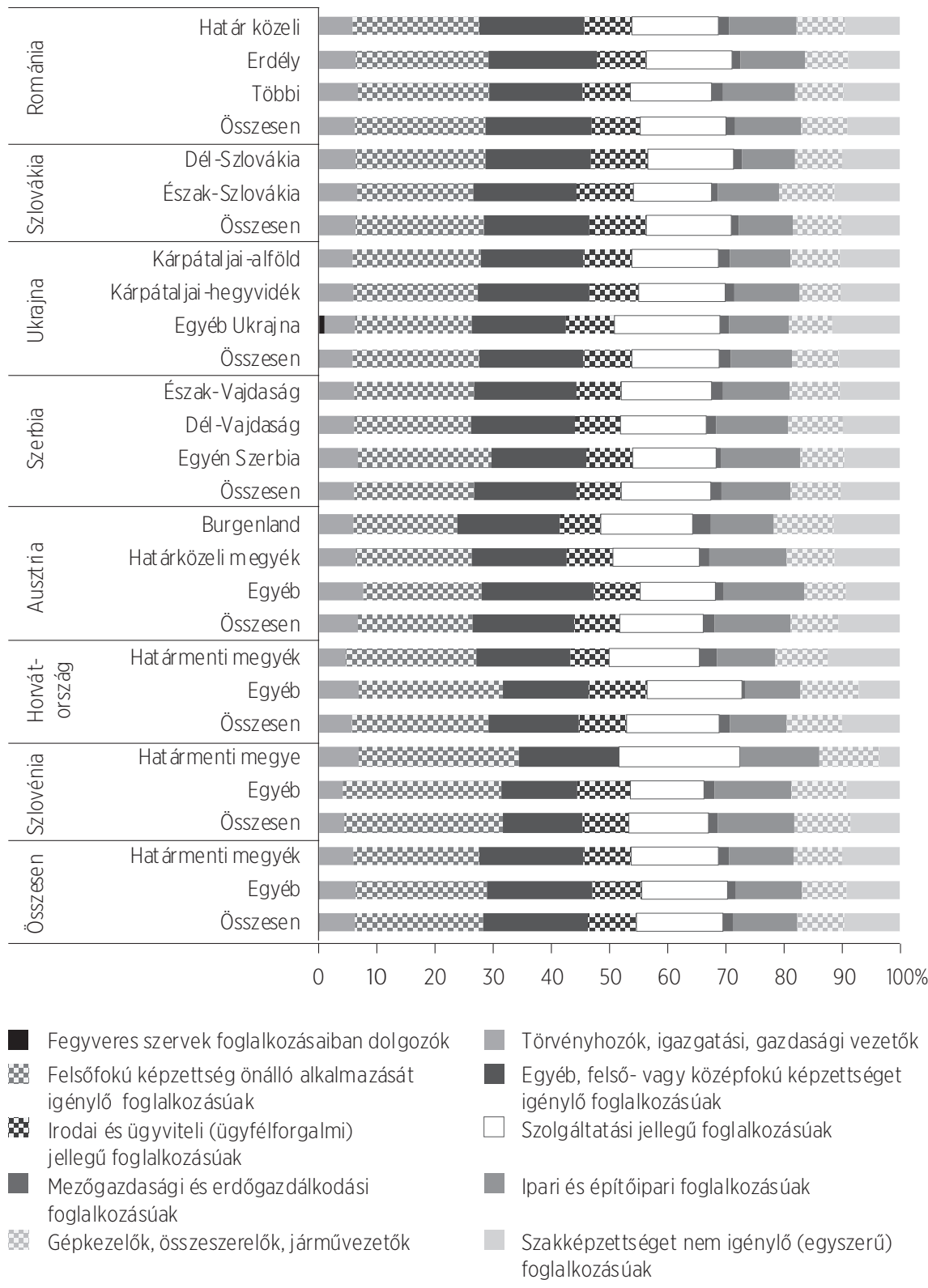

Forrás: Saját kalkuláció a BM és a KSH adatok alapján. 
A foglalkozások szerinti eloszlások nem mutatnak jelentős területi differenciálódást, általánosságban igaz tehát, hogy a szakképzettséget nem igénylő foglalkozásokat a felsőfokú képzettség önálló alkalmazását igénylő foglalkozások váltják fel.

\section{A MAGYARORSZÁG FELÉ IRÁNYULÓ VÁNDORLÁSOK HA- TÁSA AZ ELVÁNDORLÁSI TERÜLETEK MAGYAR NÉPES- SÉGSZÁMÁRA}

A Kárpát-medencei magyarság népességfejlődésében fordulópontot jelentett a harmadik demográfiai katasztrófa9 (Kocsis, 2002, 2003, 2015, Kocsi et al., 2015), amely az első világháborút követően a hazai népesedési folyamatokba történő mesterséges beavatkozás miatt az addig szerves népességfejlődés (melyek átsegítettek az első két katasztrófán) megtorpant (Tóth, 2018). Ugyanis a Kárpát-medencei magyar népességfejlődést egymásba kapcsolódó, egymást segítő folyamatok határozták meg: a magyarság természetes szaporodása, a migrációs egyenleg, továbbá a demográfiai és etnikai reprodukció különbségei (asszimiláció) (Kiss et al., 2012). A történelmi Magyarország keretei között ennek a három folyamatnak az eredménye biztosította a magyar népesség természetes szaporodását meghaladó gyarapodását, melynek segítségével 1918-ig a magyarok a demográfiai katasztrófák okozta népességveszteségeiken többé-kevésbé úrrá tudtak lenni. Ez egyben azt is jelenti, hogy a harmadik demográfiai katasztrófát követően az új határok közé szorított magyarok esetében már nem, vagy csak alig müködik a magyar népességfejlődést 1918-ig meghatározó törvényszerüség. Az ország kétharmad részének elcsatolásával megszűnt az addig működő (belföldi) mozgás, amely során a nemmagyar, vagy kevert nemzetiségüek a többségében magyarok által lakott központi területekre vándorolva, az ott élőkhöz asszimilálódva a magyarok számát növelték. 1918 után a belső vándormozgalom döntően már csak a lakosság területi átrendeződését, új határterületekről a centrum felé történő mozgásokkal szolgálta (Tóth, 2010, 2018.).

\footnotetext{
9 Első demográfiai katasztrófát a tatárjárás, másodikat a török hódoltság, a harmadikat a trianoni békeszerződés, a „Nagy Háború”, a negyediket pedig a II. világháború elvesztése okozta. Az 1956-os forradalom után szintén jelentős népességvesztés történt, de ez nem mérhető a fenti négy demográfiai katasztrófához.
} 
A határok megváltoztatásával az addig belföldiként detektált, ma már nemzetközi vándorlások hosszabb távon már nem a népesség szám növelésében, hanem paradox módon annak csökkenésében játszanak szerepet (Kocsis et al, 2015, Tóth, 2018). Az elvándorlási térségekben a magyarok számával arányosan csökkennek az iskoláztatási, munkaerő-piaci, kulturális, társadalmi lehetőségek, az etnikai kapcsolatok szűkülhetnek, és a szórványosodással párhuzamosan növekszik az asszimiláció valószínüsége az otthon maradók között. Ugyanakkor fontos felismerni, hogy a magyarországi és a szomszédos országokban élő magyar nyelvközösséghez tartozók létszámának, korstruktúrájának alakulása csak látszólag független egymástól. Mindaz, ami a népesedési folyamatok terén Magyarországon zajlik, csak része a magyar nyelvközösség népesedési folyamatainak, de nem azonos azzal (Tóth, 2018, Dövényi, et al, 2008).

Ebben a fejezetben célom feltárni, hogyan alakitották és alakitják a Magyarországra vándorlások a magyar etnikai térszerkezetet, a magyar etnikumú népesség területi összetételét és arányait a Kárpát-medencében. Egyrészt regionális szintű becslést adok a 2011-es népszámlálási adatok alapján ${ }^{10}$ - a Magyarországra való bevándorlások nélkül - a szomszédos országok etnikai arányaira. Másrészt kiszámítom, hogy a 2011 és 2017 közötti időszakban hogyan formálták a külhoni magyarság etnikai térszerkezetet az említett évek vándorlási tendenciái. Becslést adok továbbá a 2017-es területi etnikai arányok változásaira - a többi etnikum számának változatlanságát feltételezve -, melyek pusztán a Magyarországra vándorlások miatt következtek be.

A becslés kiindulópontjaként - frissebb adatok hiányában - a környező országok 2011-es cenzus adatai szolgáltak. Kivétel azonban Ukrajna, ahol friss népszámlálás hiányában csak a 2001-es hivatalos statisztikai információk álltak rendelkezésre"1. Ennek tekintetében Ukrajna egész területe helyett csupán Kárpátalja került be a vizsgálatokba. Az érintett országok cenzusaiban az etnikai kérdésblokkra nem kötelező a válaszadás (Ausztriában és Szlovéniában egyáltalán nincsenek ilyen jellegü adatok), ami nagyban nehezíti a pontos kép felrajzolását. A Kárpát-medence magyar etnikumú népességének 2011-es területi megoszlása - a becsléseim kiindulópontjai - a szak-

\footnotetext{
${ }^{10}$ A magyar nemzetiségüek, környező országokba történő vándorlásainak figyelembevételére az eljárás nem terjed ki, pusztán a külföldi kötődésű népesség vándorlásaira fókuszál. Ugyanakkor a Magyarországon született népesség körében a környező országokba vándorlás elenyésző, itt egy markánsan egyirányú folyamatról van szó.

" Ugyanakkor több tanulmány ad becslést a magyarok számáról és a migráció hatásairól 2017-re, de ezek nem tekinthetők hivatalos statisztikai adatoknak. Lásd: https://bgazrt.hu/wp-content/uploads/2019/05/3.Tatrai_et.al_..pdf; http://metszetek.unideb.hu/files/metszetek_201801_02.pdf
} 
irodalmak számításai szerint kerültek számbavételre (Molnár et al., 2005, Kiss et al., 2012, Kapitány, 2015, Tóth, 2018). A külhoni, 2011-es nemzetiségi arányoknál Kapitány Balázs (Kapitány, 2015) módszerére támaszkodtam, ezeket az értékeket használom a 3. táblázatban. Ennek lényege, hogy a nemzetiségükről nyilatkozók számát úgy korrigálja, hogy a választ nem adókat arányosan besorolja az adott területen az etnikumukról nyilatkozók aránya szerint ${ }^{12}$. Ez az eljárás finomítja a magyarok arányainak alulbecslését a környező országok cenzusaiban, de az eredmények így is elmaradnak a külhoni magyarok valós értékeitől.

Az eljárás eredményeinek használhatóságát több tényező is korlátozza. Egyrészt az egyes államok népszámlálási gyakorlatában módszertani eltérések figyelhetők meg. Másrészt a magyar cenzusok felülbecsülhetik a magyar nemzetiségűek arányát a külföldi kötődésű népességben (Magyarországon esetleg könnyebben vallhatja magát valaki magyarnak), így az elvándorlási térségekben a valósnál nagyobb magyar etnikumú elvándorlást detektálhat. A hazai asszimilációs folyamatról nincs pontos képünk (például, ha valaki a román etnikumhoz tartozóként jött hazánkba, és később vált magyarrá), így ezek hatásaira nem tudunk kitérni. Ezzel szemben a magyarrá Magyarországon váló személyek nem jelentenek igazi demográfiai deficitet a külhoni magyarság számára (csak akkor, ha ez a folyamat a kibocsájtó területen is bekövetkezett volna). A 2011 és 2017 közötti időszak vizsgálata során (az adatok hiánya miatt) azzal a feltételezéssel kellett élnem, hogy a környező országokból Magyarországra történő vándorlók egyenlege megegyezik ugyanezen két időpont stock típusú adatainak különbségeivel.

2011-ben a Kárpát-medencében (a történelmi Magyar Királyság területén, a volt Horvát Királyság nélkül) 26 millió ember élt, közülük 12 millióan - az itt élők 46\%-a - vallották magukat magyarnak. 2011-ben 201 ezer (a külhoni magyarság 8\%-a), 2017-ben pedig 313 ezer (külhoni magyarság 13\%-a) magyar etnikumhoz tartozó olyan személy élt Magyarországon, akik a Kárpát-medence más országában születtek.

\footnotetext{
${ }^{12}$ A feltételezést egy vizsgálat sem tudja alátámasztani, a választ nem adók körében nem volt külön kutatás, mely az etnikai arányok megbízhatóbb becsléshez vezethetne.
} 


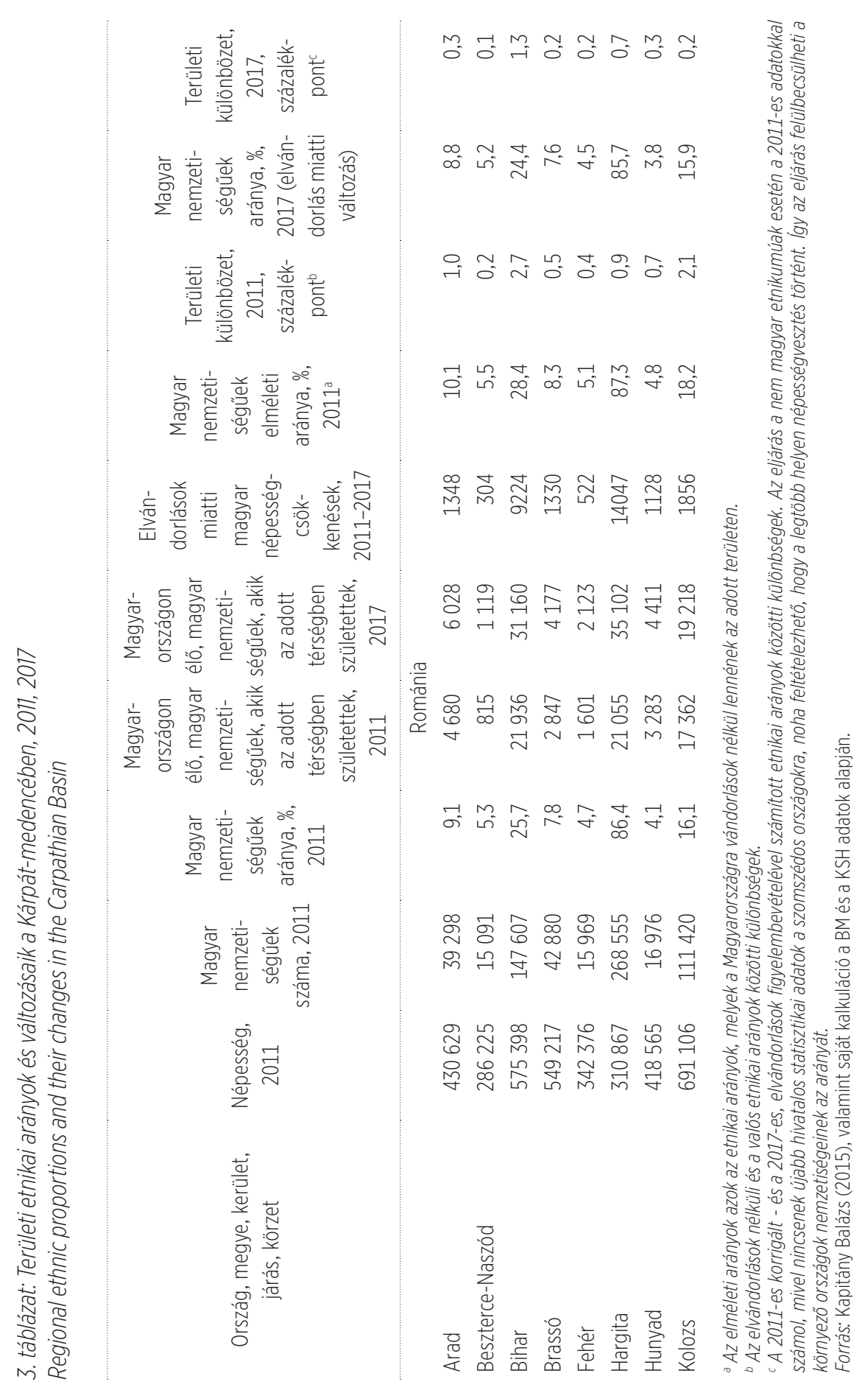


$\frac{\sqrt{2}}{\sqrt[0]{0}}$

ลิ ฐิ

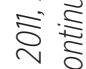

बं

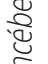

i $\infty$

8.

है

$\frac{\pi}{\sqrt{2}} \frac{\pi}{\frac{1}{1}}$

$\frac{\pi}{2} \frac{\pi}{6}$

$\frac{10}{2}$

$\div$.

帘

릴

$\frac{\pi}{2}$

出

호

궁

क.

중

这

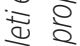

这

$\dot{\pi} \frac{\pi}{a}$

范

$\frac{\sqrt{0}}{\frac{2}{2}} \frac{2}{2}$

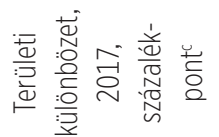

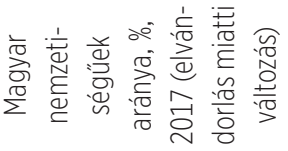

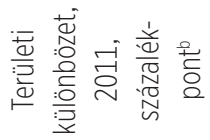

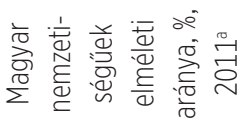

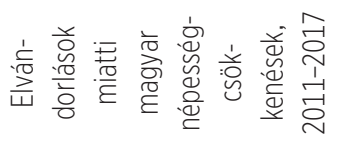

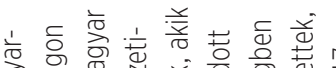

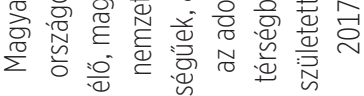

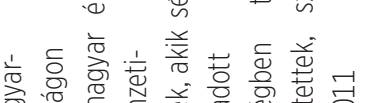

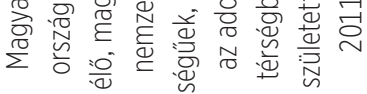

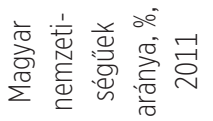

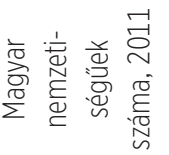

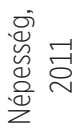

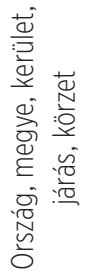

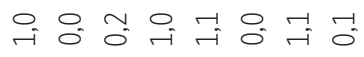

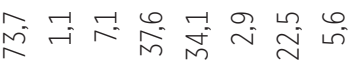

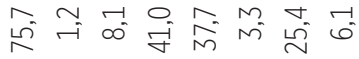

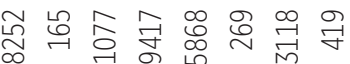

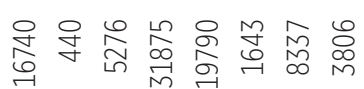

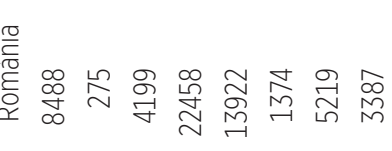

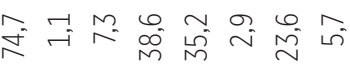

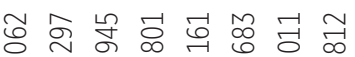
吕 m

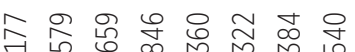

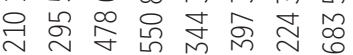

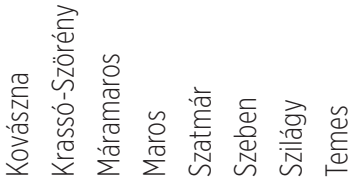

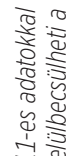

完

$\frac{2}{2}$

ष्ष

क्षे

है.

¿.

के बै

ह. ป

.

थ

준

ॠ

है के

곤

造 :

:ำ

高造

$\frac{\pi}{\frac{0}{2}} \frac{2}{\frac{0}{4}}$

$\frac{\pi}{2} \frac{2}{2}$

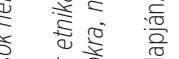

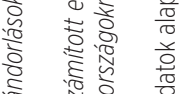

त०

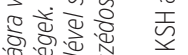

N

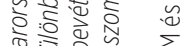

के है के के

$\sum_{0}^{\infty}: \frac{1}{0} \frac{\pi}{0} \frac{0}{0}$ :

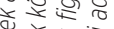

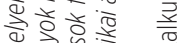

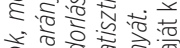

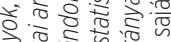

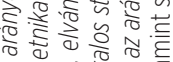

ब.

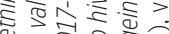

ㄱ.

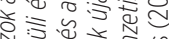

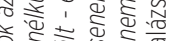

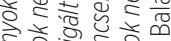

\%.

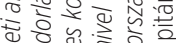

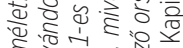

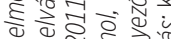

군 
$\frac{\sqrt{0}}{\frac{0}{0}}$

ลิ จ

言

बं

$\frac{8}{4}$

品

कृ. $\frac{\sqrt{2}}{8}$

$\frac{\sqrt{1}}{\sqrt{\tau}}$

$\frac{\pi}{2} \frac{1}{5}$

$\frac{\pi}{2}$

\&

$\pm$

究

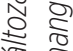

$\frac{\pi}{2} \frac{0}{2}$

压

के

$\stackrel{\frac{\pi}{8}}{\frac{\pi}{8}}$

के

$\frac{\sqrt{2}}{\frac{0}{2}}$

造

i $\frac{1}{2}$

뉸

语古

学 $\frac{2}{2}$

$\frac{\sqrt{2}}{\frac{10}{0}} \cdot \frac{8}{8}$

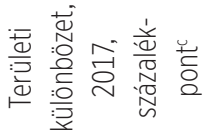

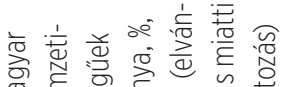

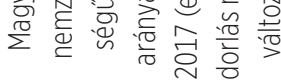

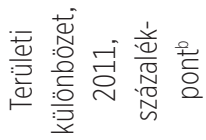

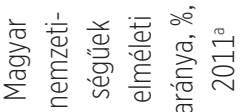

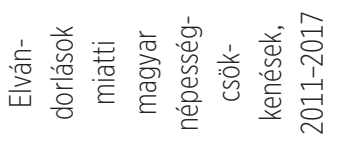

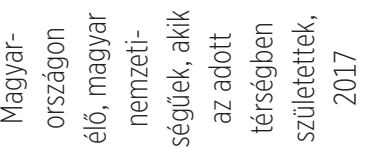

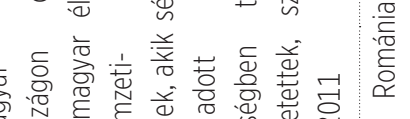

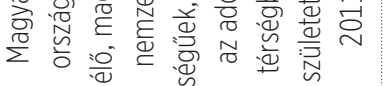

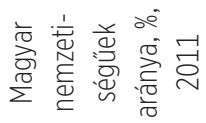
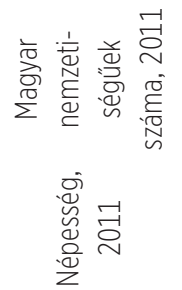

$\frac{\sqrt{2}}{\frac{9}{2}}$

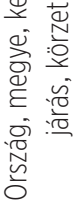

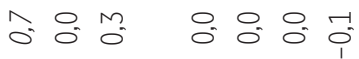

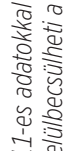

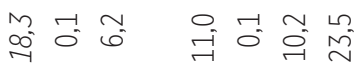

ํ.

$\frac{\sqrt{2}}{\frac{\pi}{2}}$

ฮั

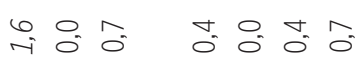

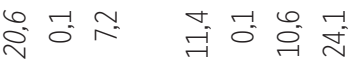

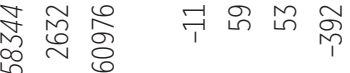

है

语

㐫造

के

है ญ

$\frac{0}{\frac{0}{0}} \frac{1}{2}$

중

$\frac{\text { बें }}{2}$

มี่

造

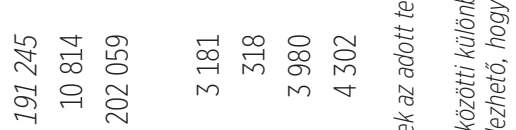

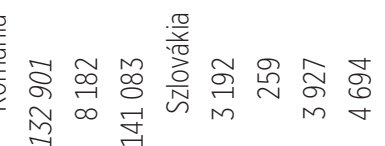

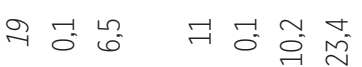

命

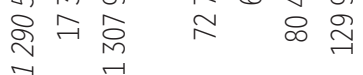

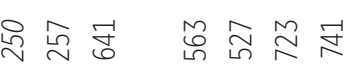

要

高这

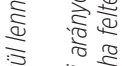

के

$\frac{\dot{\frac{\pi}{0}}}{\frac{\pi}{\frac{\pi}{0}}}$

空.

敢

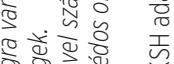

岛岛

के हूँ है

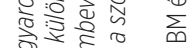

एक:

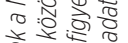

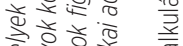

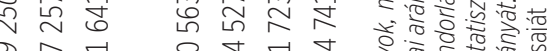

ஓ

6 유

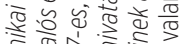

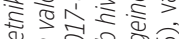

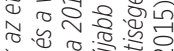

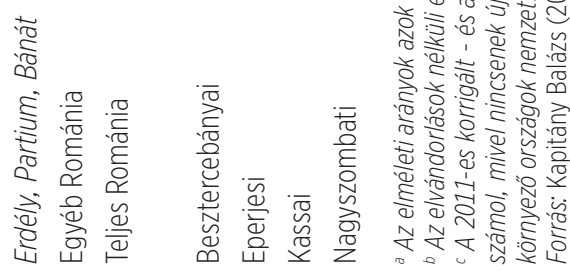


$\frac{\sqrt{0}}{\sqrt[0]{0}}$

六

言

षे

造

这

8.

हो

$\frac{\pi}{\pi} \frac{1}{5}$

$\frac{\pi}{5} \frac{\pi}{8}$

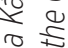

$\div$.

帘

욜

$\frac{\pi}{2}$

色:

호

들

क.

중

这

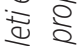

这戠

$\dot{\pi} \frac{\pi}{a}$

范

$\frac{\sqrt{0}}{\frac{2}{2}} \cdot \frac{2}{8}$

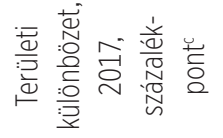

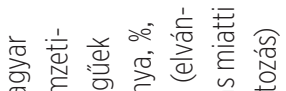

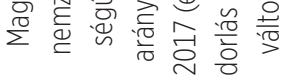

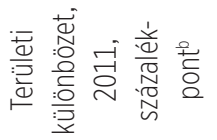

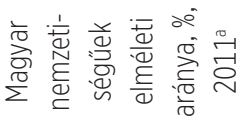

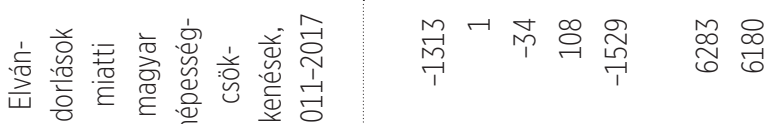

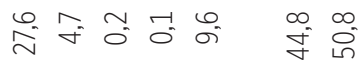

ڤूँ

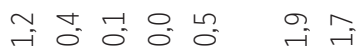

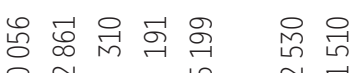
위 $\stackrel{\sim}{\sim} \underset{\exists}{\exists}$

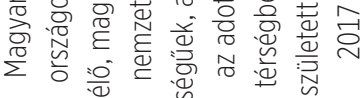

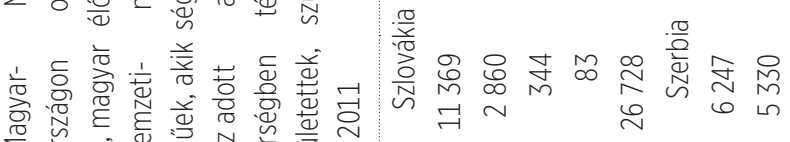

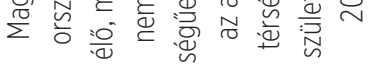

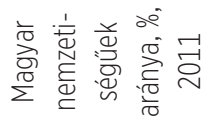

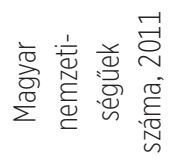
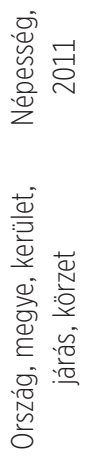

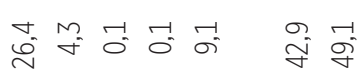

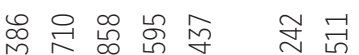

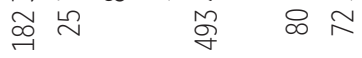

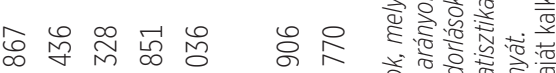

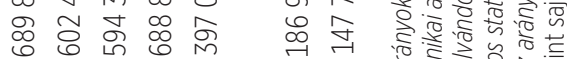

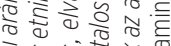
कृ. 要这

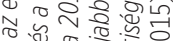
o.

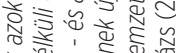

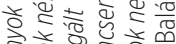

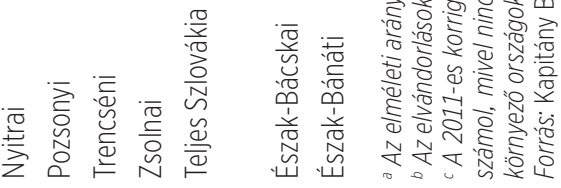




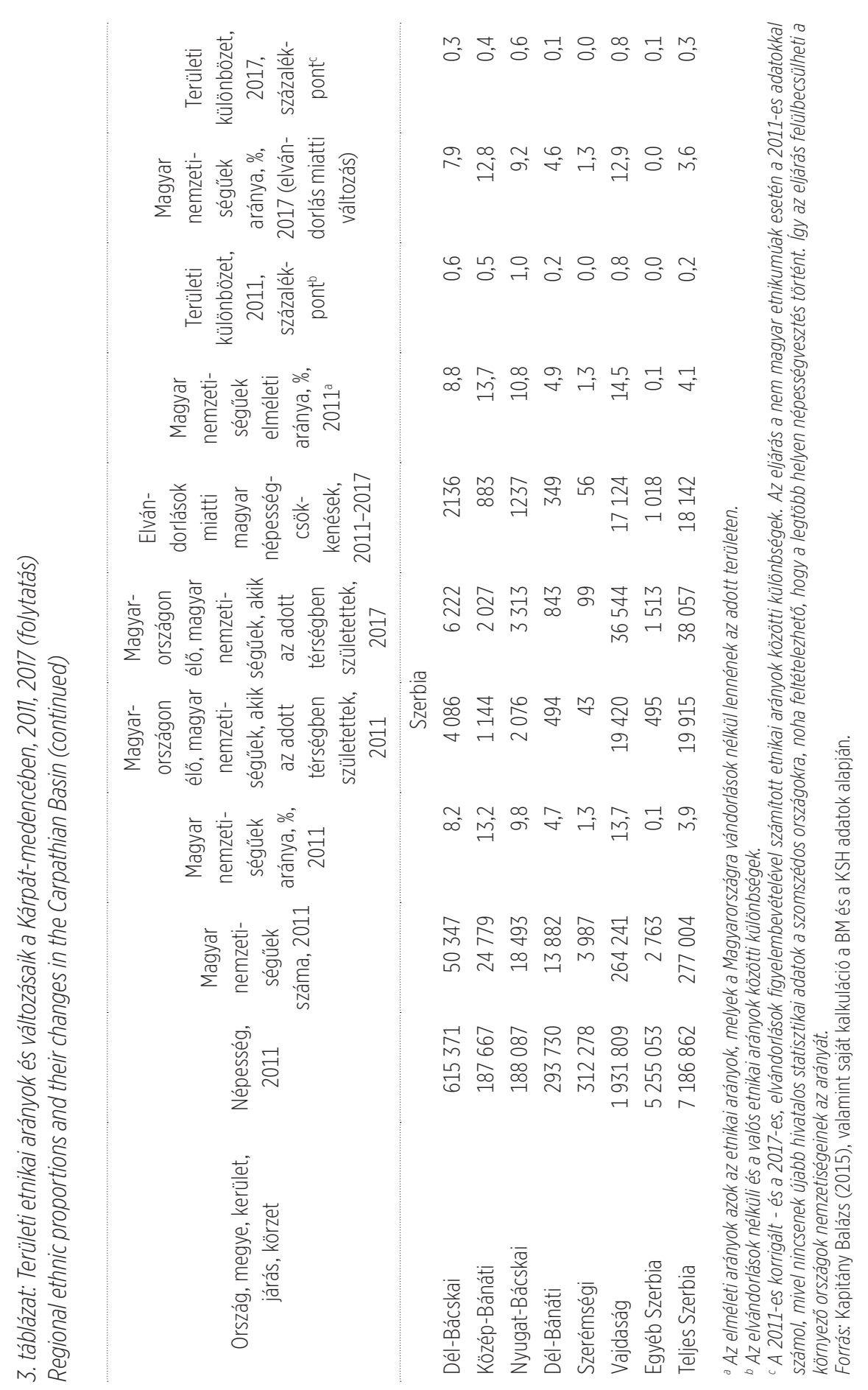


$\frac{\sqrt{5}}{\sqrt{\frac{1}{0}}}$

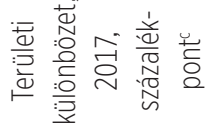

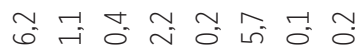

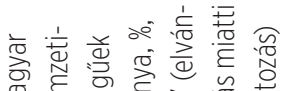

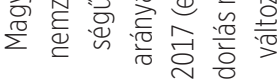

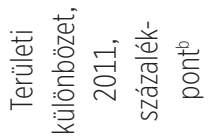

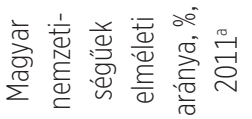

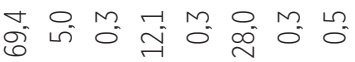

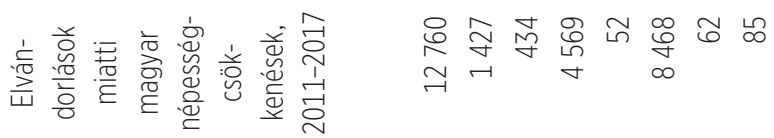
$\hat{\delta}$ m

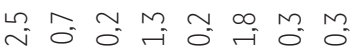

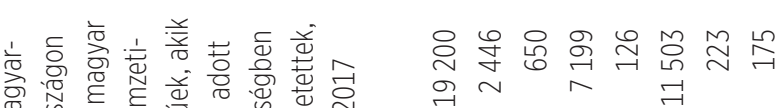
ิิ ฐิ

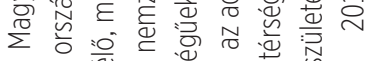

ฉิ

ह

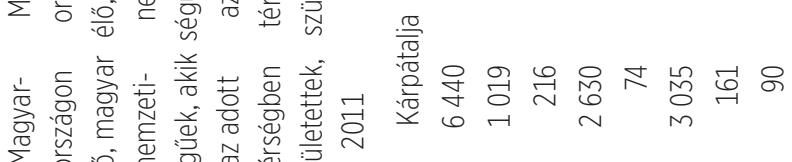

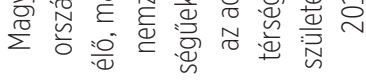

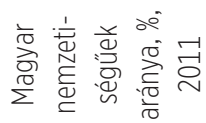

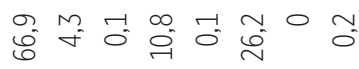
욜 帘 ㅎํㅇำ 논

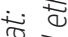
范 임 $\frac{2}{8}$

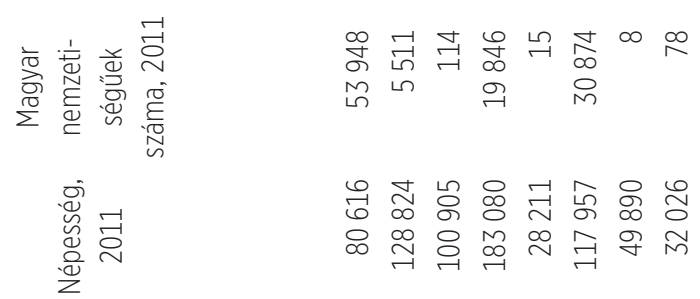

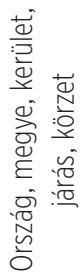

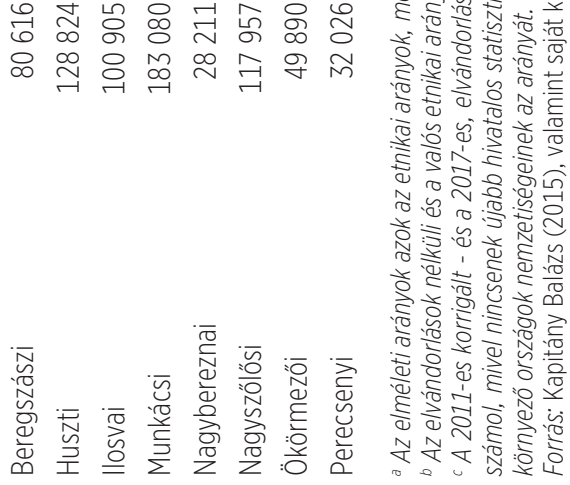




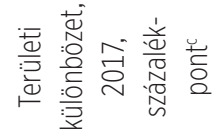

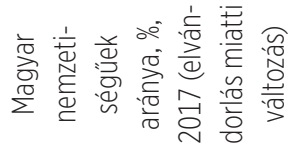

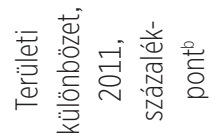

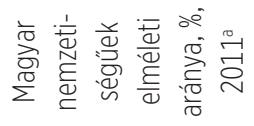

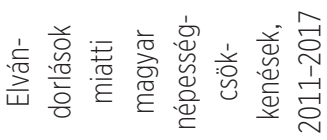

$\frac{\sqrt[n]{0}}{\frac{\pi}{0}}$

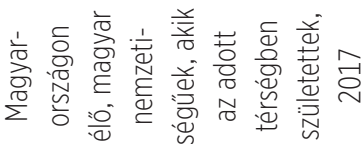

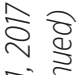

ָे

बे

造

$\stackrel{8}{\frac{1}{2}}$

$\stackrel{\frac{1}{2}}{\frac{\pi}{\pi}}$

$\frac{\pi}{\frac{\pi}{2}} \frac{\pi}{\frac{1}{5}}$

$\frac{\sqrt{2}}{2}$

$\frac{1}{2} \stackrel{2}{\frac{1}{2}}$

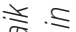

穴

늘

त)

匆

호

永 $\frac{7}{\sigma}$

r 乞

'ত

ฮ

흥

:

这

穴 $\frac{0}{\pi}$

을.

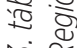

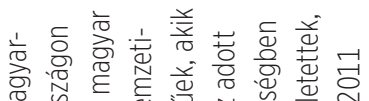

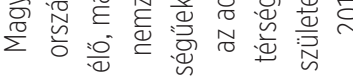

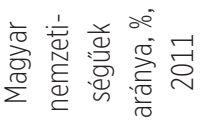

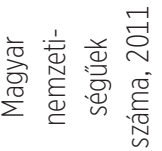

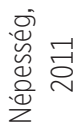

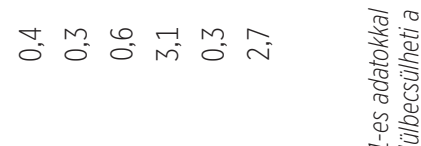

$\infty$ ․

ก

$m, \frac{1}{2}$ हे

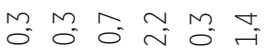

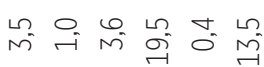

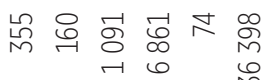

กู๊ $\sim \underset{ก}{\sim}$ ก

$\frac{.0}{\frac{0}{0}}$

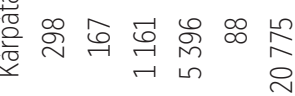

Mํํำ

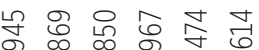

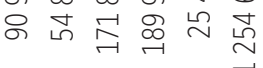

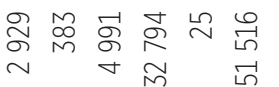

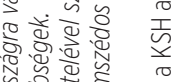

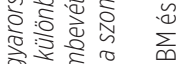

$\sum_{0}^{\infty} \frac{\pi}{0}$ बे

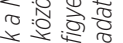

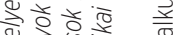

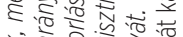

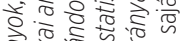

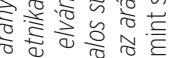

ते

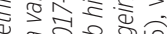

సิ

o.:.

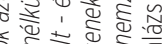

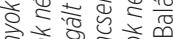

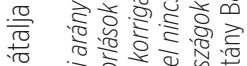

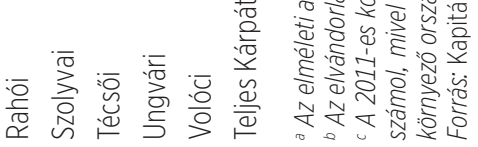




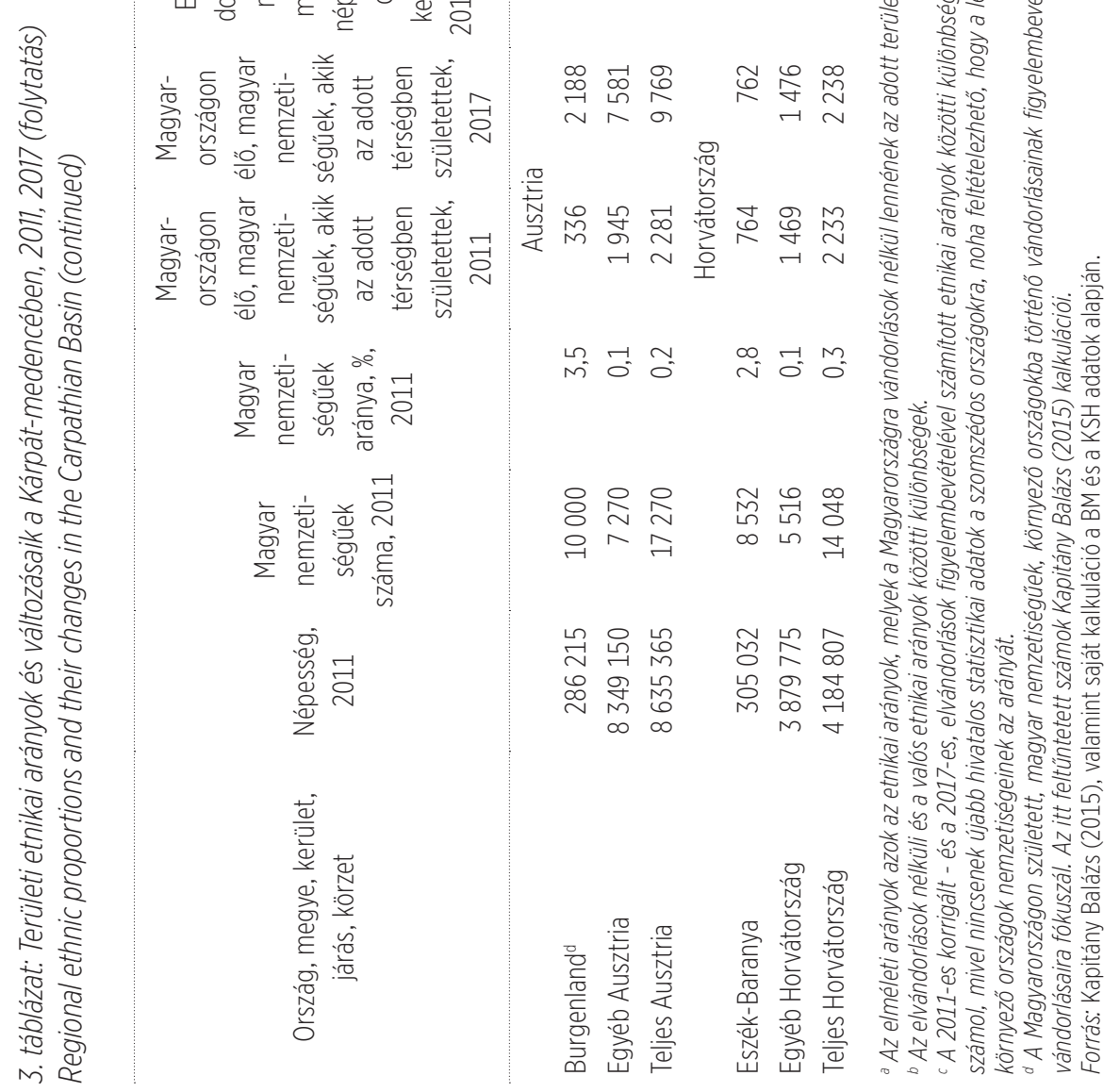

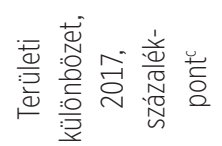

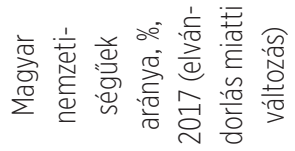

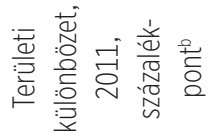

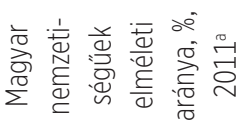

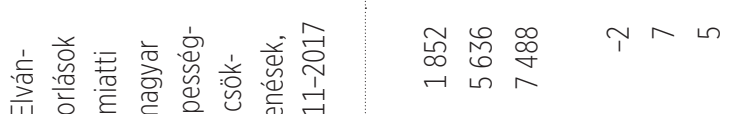

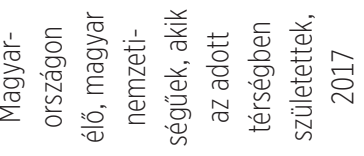

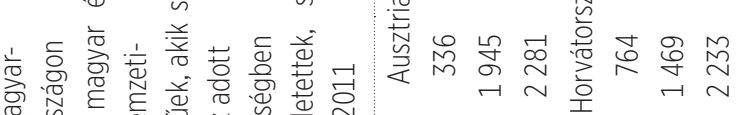

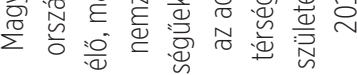

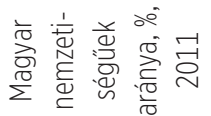

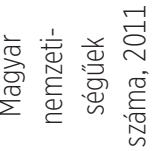

总

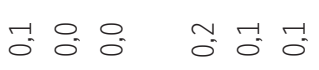

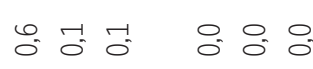

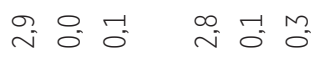

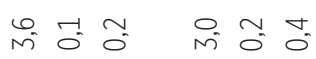

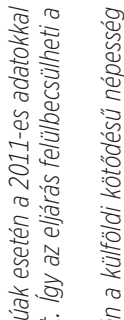

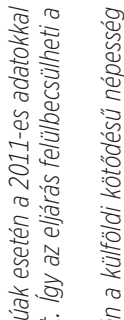

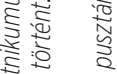

ब离节

के ले

हले है

¿.

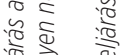

$\therefore \frac{\pi}{2}$

장 त

खें

巡

:

क्ष

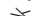

त्र

$\frac{\pi}{\pi} \frac{1}{8} \frac{\pi}{8}$

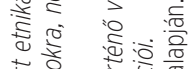

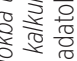

佥焉

象必

$8 \curvearrowright \Uparrow$ กิ

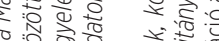
वे

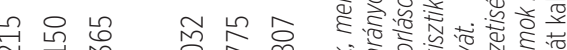
앙

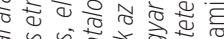
क्ष.

व

. 0 \%

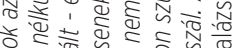

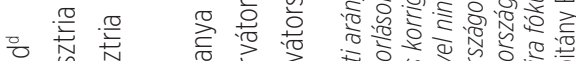

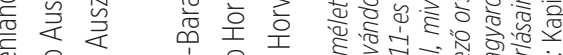

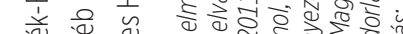

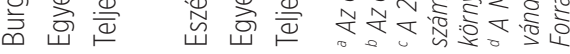




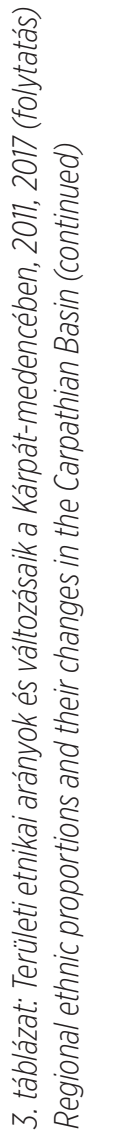

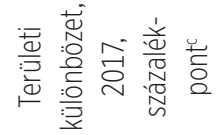

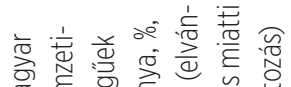

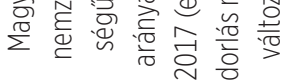

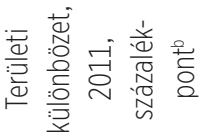

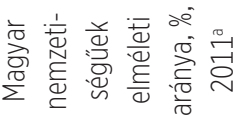

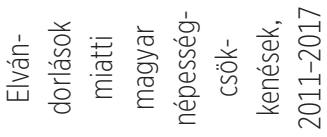

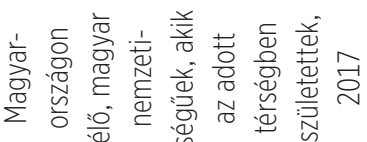

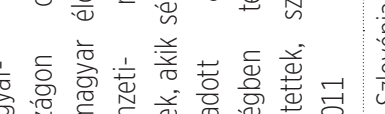

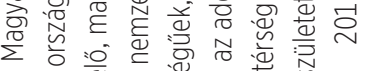
$\sum$

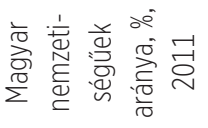

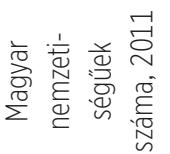
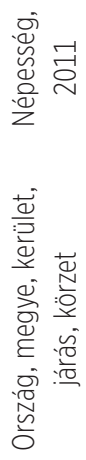

궁요

Mㅁㅇ

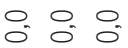

궁

M $\cong$ ก

‡

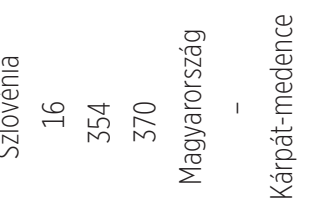

N

$\infty$

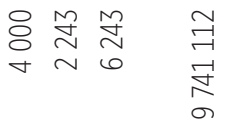

๙ ने ๙

品岕

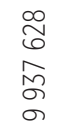

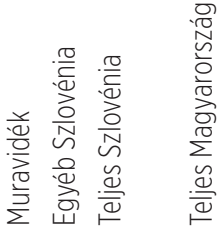

$\underset{\downarrow}{\sigma}$

$\frac{\sqrt{2}}{\frac{2}{2}}$

疍:

辛

곤 $\frac{\mathbb{2}}{4}$

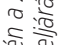

ฮั స

한흐

है.

: :

造

है जे

हญ थ



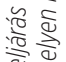

ㄱ.

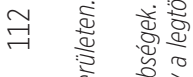

जी 芩 है

근

M ब

홍

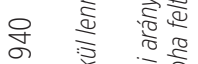

ㄹ 흐

₹

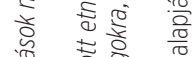

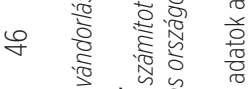

-

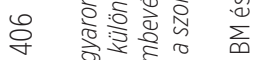

అิ

न

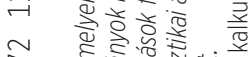

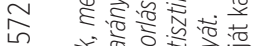

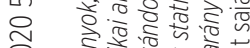

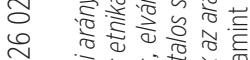

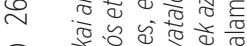

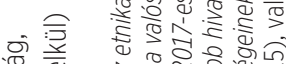

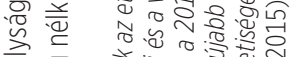

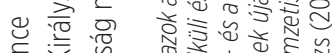

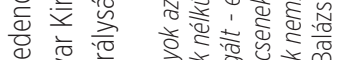

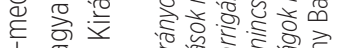

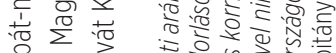

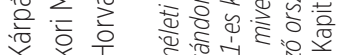

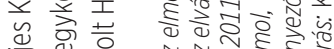
군ㄷำ 
Ha a békeszerződések előtti Magyarország területén értelmezzük a teljes nemzetközi vándorlási vertikumot, megállapíthatjuk, hogy a mozgások mintegy felét belföldi vándorlásként detektálnánk. Az I. és II. világháborút lezáró békeszerződések következményei, a határokon túl nyúló nyelvi, kulturális kapcsolatok ma is meghatározók a Kárpát-medence vándorlási folyamataiban (Tóth, 2005). Az adatok alátámasztják, hogy az I. világháború előtti időkre jellemző trend folytatódik a vándorlások karakterisztikájában a központi területeken (Magyarország), amikor a peremterületekről az ország középpontja felé történő mozgások voltak jellemzők¹3. Ezek a mozgások sok esetben nem egyirányú események, ezáltal felerősödik a cirkuláris migráció jelensége (Illés et al., 2009). A mai határokon átnyúló vándorlások egyre kevésbé jelentenek végleges letelepedési szándékot, sokkal inkább az életpálya egy-egy állomásaként (Hatton and Williamson, 2005) foghatók fel. Azaz időbeli késéssel az esetek egy részében ellenirányú mozgások (a szülőföldre történő visszavándorlás) valószínüsíthetők (2012 és 2017 között Magyarországra bevándorolt román állampolgár száma 21475 fő volt) szinte ugyanannyi (21313 fő), mint ahányan ugyanezen időszak alatt elhagyták hazánkat. Többségük visszavándorolt Romániába, kisebb részük pedig más országokba telepedett le.

Fontos hangsúlyozni, hogy a külhoni területekről Magyarországra történő vándorlások a magyarság Kárpát-medencei összlétszámát rövidtávon nem változtatják meg. Hosszabb időhorizonton azonban csökkenthetik azt, mivel az etnikai térszerkezetet jelentős befolyásolhatják: lokálisan, az elvándorlási térségekben a magyarok számával arányosan csökkennek az iskoláztatási, munkaerőpiaci, kulturális, társadalmi lehetőségek, az etnikai kapcsolatok szükülhetnek, és a szórványosodással párhuzamosan megjelenhet, vagy felgyorsulhat az asszimiláció (Tóth, 2018), ha a többi etnikai csoport számossága nem csökken a magyarnál nagyobb mértékben.

2011-es adatok alapján hazánkban a vándorlások miatt legnagyobb mértékben Kárpátalja magyar etnikumának aránya csökkent (a 12,1\%-os etnikai arány 13,5\% lenne, ha 21 ezer fő nem dönt a régió elhagyása mellett), ahol a Beregszászi és az Ungvári járások voltak a leginkább érintettek (2,5, illetve 1,8 százalékponttal csökkentve a magyar etnikum arányát az adott járásban).

A 2011-es népszámlálás szerint a Magyarországra való vándorlások száma nélkül Erdély lakosságának 21\%-a lenne magyar, de a vándorlásokat is figyelembe véve a ráta 19\%-os. A leginkább érintett megyék Bihar (2,7 százalékpontos különbség), Szatmár (2,5), Maros (2,4) és Kolozs (3,8). Ezeken a területeken él az erdélyi magyarság csaknem fele.

${ }^{13}$ A Kárpát-medence határon túli régióinak vándorlási mintázatát ellenben nem ismerjük. 
A Vajdaságban élő magyar nemzetiségűek aránya 14,5\% lett volna, ha közel 20 ezren nem költöznek át 2011-ig Magyarországra (így 13,7\%). A magyar etnikumúak arányai a legnagyobb mértékben az Észak-Bánáti (1,7 százalékpont) és az Észak-Bácskai (1,9) körzetekben csökkent.

Szlovákiában 2011-ben 9,1\%-os volt az előző népszámlálás során a magyarok aránya, míg az elvándorlások nélkül fél százalékponttal magasabb, 9,6\%-os értéket mérhettünk volna. Itt a legnagyobb csökkenés a Nyitrai kerületben (1,2 százalékpont) volt, 2011-ben már 11 ezer ott született ember élt hazánkban.

Ausztria, Szlovénia és Horvátország esetén nem történt számottevő változás az etnikai térszerkezetben a külföldön született népesség Magyarországra vándorlásai miatt. Jóllehet közel 100000 magyar dolgozik nyugati szomszédunknál az osztrák társadalombiztosítási adatok szerint ${ }^{14}$, akiknek kisebb részük kivándorolt Magyarországról, míg nagyobb hányaduk ingázó. Így a magyar nemzetiség jelenléte Ausztriában összességében növekedett az általam elemzett időszak alatt.

A 2011 óta eltelt időszakot vizsgálva megállapítható tehát, hogy a Kárpát-medencében az elvándorlás következtében a kárpátaljai magyarság fogyása vált arányaiban a leggyorsabbá (2017-ben 9,4\% a magyarok aránya a becslések szerint, 2,7 százalékponttal kevesebb az előző értéknél). A Beregszászi járásban alig maradt 60\% felett a magyarok aránya a 2011-es 66,9\%-hoz képest, ha a többi etnikum számának változatlanságával számolunk. Kárpátalja magyarok lakta járásainak jóval kedvezőbb demográfiai helyzete és az általánossá váló kivándorlások tompítják az elméleti etnikai szerkezeti eltolódást (Karácsonyi et al., 2014).

Romániában 2017-re a becslés szerint 6,2\%-ra mérséklődött a magyarok aránya (a 6,5\%-os 2011-es értékről). Ez a folyamat leginkább Bihar megyét érintette, ahol a magyarok aránya 24,4\%, míg a 2011-es népszámlálás szerint arányuk 25,7 $\%$ volt.

A tovább folytatódó Észak-Bácskai és Észak-Bánáti kiáramlások miatt a Vajdaságban a 2011-es 13,7\%-ról 2017-re 12,9\%-ra mérséklődhetett a magyar etnikumúak aránya.

Szlovákiában azonban megállt a magyarok Magyarországra költözése, inkább a visszavándorlások a jellemzők, így az etnikai szerkezet is többé-kevésbé változatlan maradt 2017-re. Hasonló arány és visszavándorlás jellemzi az eddig nem említett vizsgált országokat is.

\footnotetext{
${ }^{14}$ http://www.hauptverband.at/cdscontent/?contentid=10007.754024\&viewmode=content
} 


\section{ÖSSZEFOGLALÓ}

A Magyarországot érintő nemzetközi vándorlásban egyszerre van jelen a globális migrációs hatás, valamint a környező országok és hazánk közötti folyamatok, melyek hosszú időre nyúlnak vissza. A nemzetközi migráció hazai jellegzetessége, hogy a bevándorló népesség nagy része magyar nemzetiségü, illetve magyar anyanyelvü. A határon túl nyúló nyelvi, kulturális kapcsolatok erőssége elsősorban az I. és II. világháborút lezáró békeszerződések következménye.

A szomszédos országokban élő kisebbség reprodukciója nem pusztán a természetes demográfiai folyamatok kérdése, hanem jelentős szerepet játszanak benne a vándorlások is. A Magyarországra érkezők csökkentik az elvándorlás térségének magyar népességszámát, ahol a legtöbb esetben ettől függetlenül is népességvesztés történik természetes népmozgalmi okokból. Ahol pedig növekedhetne a magyarság lélekszáma, ott a vándorlás az esetek egy részében „elviszi” ezt. Másrészt a vándorlás, mivel korspecifikus folyamat, közvetett hatások révén befolyásolja a forrásterületek társadalmi-gazdasági folyamatait (eltartottsági ráta, átlagéletkor, gazdaságilag aktívak aránya stb.). A külhoni területekről Magyarországra történő vándorlások a magyarság Kárpát-medencei összlétszámát rövidtávon nem változtatják meg, azonban hosszabb időhorizonton csökkenthetik, mivel az etnikai térszerkezetre jelentős befolyásuk van.

Az 1980-as évek végén, és az 1990-es évek elején bekövetkezett népességmozgások tették egyértelművé számunkra, hogy a magyar nyelvközösség körében lejátszódó demográfiai folyamatokat - az 1918-ban bekövetkezett széttagoltság, és a közel 100 éves „szétfejlődés” ellenére - csak akkor ismerhetjük meg, ha azokat együtt, egységes folyamatként vizsgáljuk. Fontos felismerni, hogy a demográfiai folyamatok a jelenlegi határok mentén és a határ túloldalán is hasonló jellegűek. Kérdés viszont, hogy Európán belül nemcsak mint történelmi, hanem mint demográfiai régió is létezik-e Közép-Európa (Tóth, 2018).

Tehát mindaz, ami a népesedési folyamatok terén Magyarországon zajlik, csak része a magyar nyelvközösség népesedési folyamatainak, de nem azonos azzal. Cél ezáltal nemcsak a magyarországi, hanem a Kárpát-medencei magyarság létszámcsökkentésének megállitása is lehet. Ennek megvalósitása nem egyszerü feladat, mert ellentétes a szomszédos országok érdekeivel. Kérdés tehát, hogy a mai magyar népességfejlődés mennyire lehet folytatása az 1918-as évet megelőző évszázadoknak. 
A tanulmányban leírt vándorlási folyamatok még jelentősebb hatással lennének a magyarság Kárpát-medencei etnikai térszerkezetére és létszámára, ha a többi etnikum száma nem csökkenne hasonlóan a magyarhoz. A szülőföldön maradás erősödése, a visszavándorlások számának, illetve a helyi magyarság termékenységi rátájának emelkedése jelenthetne megoldást a problémára. Mindezzel talán elérhető lenne, hogy a Kárpát-medencében újra növekedjen a magyarok száma, amivel 50\% fölé is emelkedhetne az arányuk. Ennek a folyamatnak jelenleg legnagyobb gátja az a népességveszteség, amely az alacsony termékenység, a magas halálozás következtében a Kárpát-medence magyar népességét éri.

\section{Köszönetnyilvánítás: A tanulmány a Bolyai János Kutatási Ösztöndíj támogatásával készült.}




\section{IRODALOM}

Venables, Anhony J. (1998). The assessment: trade and location, Oxford Review of Economic Policy, (14)2,1-6.

Bálint L., Obádovics Cs. (2017). Belföldi vándorlás. In Monostori Judit, Őri Péter, Spéder Zsolt (szerk.). Demográfiai portré 2018 (217-236. o.). Budapest: KSH NKI.

Blaskó Zs., Gödri I. (2016). A Magyarországról kivándorlók társadalmi és demográfiai összetétele. In Blaskó Zs., Fazekas K. (szerk.), Munkaerőpiaci tükör 2015, (59-68. o.). Budapest: MTA Közgazdaság- és Regionális Tudományi Kutatóközpont Közgazdaságtudományi Intézet.

Dövényi Z., Tóth P. P. (2008). Immigration, reception and integration in Hungary. In Kertész Á. és Kovács Z. (szerk.). Dimensions and trends in Hungarian geography: Dedicated to the 31st International Geographical Congress, Tunis, 12-15 August 2008. (Studies in Geography in Hungary; 33.) (111-123. p.). Budapest: Geographical Research Institute, Hungarian Academy of Sciences.

Dövényi Z. (2011). A Magyarországot érintő nemzetközi vándorlás területi aspektusai. In Tarrósy I., Glied V., Keserű D. (szerk.). Új népvándorlás: Migráció a 21. században Afrika és Európa között. (85-95. o.) Pécs: Publikon Kiadó.

Egedy T. (2017). A külföldre ingázás statisztikai, demográfiai és területi jellemzői Magyarországon. Területi statisztika, 57(4), 385-405.

Gárdos É., Sárosi A., Kincses Á., Nagyné Forgács E. (2008). Integrated Database of International Migration Statistics with a Particular Attention to Linking Data Sources. Hungarian statistical Review, 12(86),75-87.

Gellérné Lukács É. és Szigeti B. (2005). Munkavállalási szabályok az EU tagállamaiban az átmeneti idő alatt. Budapest: KJK Kerszöv.

Gödri I. (2011). A Magyarországon élő külföldiek jellemzőinek területi sajátosságai és ezek összefüggése a munkaerő-piaci helyzetükkel. Demográfia, 54(2-3), 81-120.

Gödri I. (2012). Nemzetközi vándorlás.In Demográfiai portré - jelentés a magyar népesség helyzetéről 2012 (137-154. o.). Budapest: KSH NKI.

Hatton, Timothy J. and Williamson, Jeffrey G. (2005). Global Migration and the World Economy: Two Centuries of Policy and Performance, Mass. Cambridge: MIT Press.

Illés S. (2008). Indirect estimation on the types of internatoinal elderly migration in Hungary. Romanian Review on political Geography, 8(1), 55-63.

Illés S. és Kincses Á. (2009). Cirkuláció és migráció Magyarország nemzetközi vándormozgalmában. Statisztikai Szemle 87 (7-8), 729-747.

Juhász A., Molnár Cs., Zgut E. (2017). Menekültügy és migráció Magyarországon. Prága: Heinrich-Böll-Stiftung e.V., Budapest: Political Capital.

Kapitány B. (2015). Külhoni magyar közösségek. In Demográfiai portré 2015 (227-240. o.). Budapest: KSH NKI.

Karácsonyi D., Kocsis K., Kovály K., Molnár J., Póti L. (2014). East-West dichotomy and political conflict in Ukraine - Was Huntington right?. Hungarian Geographical Bulletin 63(2), 99-134. DOI: 10.15201/hungeobull.63.2.1

Kincses Á. (2014). Nemzetközi migrációs körkép Magyarországról a 2011-es népszámlálási adatok alapján. Területi Statisztika, 54(6), 590-605. 
Kiss T. és Barna G. (2012). Népszámlálás 2011. Erdélyi magyar népesedés a XXI. század első évtizedében Demográfiai és statisztikai elemzés. Kolozsvár: Nemzeti Kisebbségkutató Intézet.

Kocsis K. (2002). Etnikai földrajz. In Tóth J. (szerk.), Általános társadalomföldrajz I.. Budapest-Pécs: Dialóg Campus Kiadó. http://www.tankonyvtar.hu/hu/tartalom/tamop425/2011_0001_528_Toth_Jozsef_Altalanos_tarsadalomfoldrajz_III/ ch06s04.html

Kocsis K. (2003). A Kárpát-medence etnikai földrajza (896-1989). Budapest: MTA CSFK Földrajztudományi Intézet.

Kocsis K., Bottlik Zs., Tátrai P. (2006). Etnikai térfolyamatok a Kárpát-medence határainkon túli régióiban (1989-2002). Budapest: MTA FKI.

Kocsis K. (2015). A Kárpát-medence etnikai térképsorozata (Erdély, Szlovákia, Kárpátalja, Vajdaság, Horvátország, Muravidék, Őrvidék, Magyarország). Budapest: MTA Földrajztudományi Kutatóintézet.

Kocsis K., Tátrai P., Agárdi N., Balizs D., Kovács A. (2015). A Kárpát-Pannon-térség változó etnikai arculata a 15. század végétől a 21. század elejéig. Budapest: MTA CSFK Földrajztudományi Intézet. http://www.mtafki.hu/konyvtar/karpat-pannon2015/pdf/ Changing_Ethnic_Pattern_Carpatho_Pannonian_Area_2015.pdf

Krugman P. és Venables, A. J. (1996). Integration, Spetialization, and Adjustment, European Economic Review, 40959-968.

Központi Statisztikai Hivatal (2017). Új magyar állampolgárok. Változások az egyszerüsített honosítási eljárás bevezetése után. Budapest, p. 64; http://www.ksh.hu/docs/hun/ xftp/idoszaki/pdf/ujmagyarallampolgarok.pdf

Mezencev K. (2010). A területi egységek lehatárolásának tökéletesítése Ukrajnában az Európai Unió normái szerint. Területi statisztika, 13(50). 56-66.

Molnár J. és Molnár D. I. (2005). Kárpátalja népessége és magyarsága a népszámlálási és népmozgalmi adatok tükrében.Kárpátaljai Magyar Pedagógusszövetség.

Rédei M. (2007). Mozgásban a világ, a nemzetközi migráció földrajza. Budapest: Eötvös Kiadó.

Siskáné Szilasi B., Halász L., Gál-Szabó L. (2017). A magyar fiatalok erősödő kivándorlási szándékának kiváltó okai és jellemzői. Tér és Társadalom, 31(4), 131-147. doi:10.17649/ TET.31.4.2885

Tátrai P., Molnár J., Molnár D. I., Kovály K., Erőss Á., Ferenc V., Rákóczi K. (2018). A migrációs folyamatok hatása a kárpátaljai magyarok számának alakulására. Metszetek 7(1). 5-29. DOI 10.18392/metsz/2018/1/1

Tóth P. P. (1999). Szórványban, A magyar vegyes (magyar-román, román-magyar) családok helyzete Észak-Erdélyben 1942-1944 között. Budapest: Püski Kiadó.

Tóth P. P. (1997). Haza csak egy van? Menekülök, bevándorlók, új állampolgárok Magyarországon. Budapest: Püski Kiadó.

Tóth P. P. (2005). A szomszédos országokból bevándorlók lakóhelyi és kulturális jellemzői. Korfa, 2005(2-3), 3-7.

Tóth P. P. (2010). A magyar népességfejlődés meghatározottsága (Múlt, jelen, jövő). Müvelödés, 2010(4), 153-163. http://www.muvelodes.ro/index.php/Cikk?id=956

Tóth P. P. (2018). A Kárpát-medencei magyar népességfejlődés, Globe Edit. 


\section{HUNGARIAN INTERNATIONAL MIGRATION IN THE CARPATHIAN BASIN BETWEEN 2011 AND 2017}

\section{ABSTRACT}

There are two distinct levels of international migration affecting Hungary: the influences of global migration and the processes between neighbouring countries and Hungary. The characteristic feature of international migration in Hungary is that the majority of the immigrant population are of Hungarian nationality, which is partly due to the consequence of the First and the Second World War.

The migration of Hungarian ethnicity from abroad to Hungary does not change the total number of Hungarians in the Carpathian Basin in the short term. However, they are reduced over a longer time horizon, as they have a significant influence on the ethnic spatial structure: locally, in the immigration regions, the number of opportunities have been decreased in line with the declining number of Hungarians, and assimilation may appear. Population movements after the change of regime made it clear that the demographic processes taking place in the Hungarian language community - despite the fragmentation from 1918 and the almost 100 years of fragmentation - can only be known if we examine them together as a unified process. All that happens in Hungary is only part of the demographic processes of the Hungarian language community. The aim is not only to stop the decreasing number of Hungarians in Hungary, but to stop them falling in the Carpathian Basin. Realizing this is not an easy task, because it is against the national interests of neighbouring countries.

Of the foreign born population in Hungary the number of migrants, who come from territories of non-Hungarian ethnicity is increasing, and among them the assimilation to Hungarians can be detected, where the demographic processes of the pre-1918 period can be recognized. How can the development of Hungarian population be put in continuity to the centuries before 1918 is questionable.

The migration processes described in the study would have a significant impact on the ethnic spatial structure and number of the Hungarians in the Carpathian Basin if the number of other ethnicities did not decrease similarly to the Hungarians. Strengthening staying in the birth country, and increasing the number of returnees and rate of fertility in the whole Carpathian-Basin could solve the problem. The goal would be to increase the proportion of Hungarians to $50 \%$ in the Carpathian Basin. The biggest obstacle to this process is the loss of existing population which, due to low fertility and high mortality rates, affects the Hungarian population of the Carpathian Basin.

Keywords: Demography, Carpathian Basin, International Migration, Statistics 